\title{
Travails of the Entrepreneurial Ant: Reforming Tax-Favored Retirement Saving for SMall Business Owners
}

Edward A. Morse

Follow this and additional works at: https://via.library.depaul.edu/law-review

\section{Recommended Citation}

Edward A. Morse, Travails of the Entrepreneurial Ant: Reforming Tax-Favored Retirement Saving for SMall Business Owners , 50 DePaul L. Rev. 49 (2000)

Available at: https://via.library.depaul.edu/law-review/vol50/iss1/3

This Article is brought to you for free and open access by the College of Law at Digital Commons@DePaul. It has been accepted for inclusion in DePaul Law Review by an authorized editor of Digital Commons@DePaul. For more information, please contact digitalservices@depaul.edu. 


\title{
TRAVAILS OF THE ENTREPRENEURIAL ANT: REFORMING TAX-FAVORED RETIREMENT SAVING FOR SMALL BUSINESS OWNERS
}

\author{
Edward A. Morse*
}

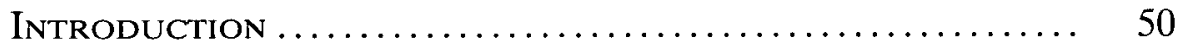

II. Overview of Tax-Favored Retirement Savings .. 56

A. Timing Principles for Income and Deductions...... 56

1. Income............................ 57

2. Deductions......................... 58

3. Application to Deferred Compensation (NonQualified Plans) ........................ 59

B. Principles Governing Tax-Favored Retirement

Savings: Employer-Sponsored Qualified Plans,

Individual Retirement Accounts, and Keogh Plans ..

1. Employer-Sponsored Qualified Retirement

Plans ............................... 63

2. Individual Retirement Accounts ............ 71

3. Keogh Plans and Other Options for the Self-

Employed ........................... 74

C. Wealth Accumulation Advantages From Tax-Favored Treatment .............................. 75

D. Conditions and Restrictions Affecting Participation and Access to Retirement Funds.............. 80

1. Conditions Requiring Participation ........... 82

2. Restrictions on Access to Retirement Savings .... 83

3. Restrictions on Investments................ 88

III. Empirical Data on Participation................ 90

A. Employee Benefits Research Institute Surveys ...... 91

B. Statistics of Income Data ..................... 94

IV. Tax Consequences of Business Investments and

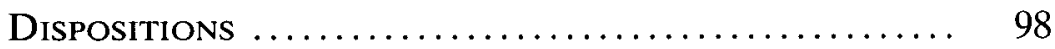

A. Investments In Business Assets ............... 98

B. Sales of Business Property ............... 103

* Associate Professor of Law, Creighton University School of Law. J.D., University of Michigan Law School 1988; B.S.B.A., Drake University 1985. The author acknowledges the helpful comments of Kathryn L. Moore, and the research assistance of Jennifer Long (Creighton Law School, Class of 2001) in the preparation of this article. 
C. Dispositions at Death ........................... 105

V. Suggested Reforms .......................... 106

A. Expanded Loan Availability and Penalty Exemptions ..................................... 107

B. Expanded Contribution Options at Transition Events .................................. 108

\section{INTRODUCTION}

The ant has long endured as a model of responsible planning and saving. ${ }^{1}$ In Aesop's fable, ${ }^{2}$ ants worked diligently to store up winter provisions, while the grasshopper danced and played, ridiculing the ants for their hard work and saving ethic. When winter's snowy blanket covered the land, the grasshopper came to the ants searching for food. Without personal savings or a "safety net" from government, family, or charity to protect him, the grasshopper faced rather bleak prospects in the winter of his life, unable to work in order to sustain himself.

Aesop's fable involved a simple world without government programs to influence retirement saving practices or ameliorate poverty. The ants presumably worked and saved simply to avoid the grasshopper's fate, albeit in the cooperative context of their colony. ${ }^{3}$ The grasshopper pursued a path of consumption unaffected by programs that might require or encourage saving, or provide relief from the consequences of failing to save.

Welfare and retirement security policies reflect our collective discomfort with the grasshopper's predicament. Welfare programs are designed to ensure that those who fall into poverty, for whatever reason and in whatever age group, are not left to depend solely on discre-

1. See The Book of Virtues: A Treasury of Great Moral Stories 354-55 (William J. Bennett, ed. 1993) ("The ant, like the bee, has long been held up as a paradigm of industriousness."). In the Bible, the ant is touted as a role model for self-motivated work and saving:

Go to the ant, you sluggard,

Consider her ways and be wise,

Which, having no captain, overseer or ruler,

Provides her supplies in the summer,

And gathers her food in the harvest.

Proverbs 6:6-8 (New King James).

2. See The Grasshopper and the Ants in Aesop's Fables $78-79$ (Belinda Gallagher, ed., Brimax Books 1991).

3. It should be noted that the ants were not rugged individualists. Cooperative efforts within families or communities often formed a part of the "safety net" for their members. See, e.g., United States v. Lee, 455 U.S. 254, 257 (1982) ("The Amish believe that there is a religiously based obligation to provide for their fellow members the kind of assistance contemplated by the social security system."). 
tionary charitable relief for life's necessities. ${ }^{4}$ Financing such programs through general tax revenues effectively requires productive ants to contribute toward meeting the needs of others. Tax incentives may also encourage giving to private charities, which alleviate burdens that might otherwise fall on government programs. ${ }^{5}$

Retirement security policies focus more narrowly on encouraging or requiring ant-like behavior in providing for retirement. ${ }^{6}$ These policies are based on the assumption that many people will not save enough to sustain themselves during old age. ${ }^{7}$ Accordingly, such policies seek to prevent post-retirement poverty by providing a source of replacement income for those leaving the workforce. Retirement security policies may also implement other social goals, such as redistributing wealth, ${ }^{8}$ reinforcing notions of equality, ${ }^{9}$ or promoting eco-

4. Means-tested welfare programs include food stamps, public housing, Medicaid, and Supplemental Security Income (SSI). See Eric R. Kingson \& James H. Schulz, Should Social Security Be Means-Tested?, in Social Security in THE 21st Century 41, 42 (Eric. R. Kingson \& James H. Schulz, eds., 1997). Although private charities also form a part of the social safety net, these government welfare programs reflect the view that private, discretionary relief is inadequate to address the problems of poverty. As Kingson and Schulz explain:

Early in the twentieth century, the nation rejected the approaches to social welfare that emerged from the poor-laws tradition. The county poorhouses, the orphanages, and the intrusive supervision of the poor by charity organizations were viewed as dehumanizing vestiges of a tradition dominated by programs designed, first and foremost, to minimize malingering and sloth. The basic idea of the old tradition was that the conditions of relief should be so harsh as to discourage only the most needy from seeking support. Thus, the poorhouse became the last refuge of the desperate and destitute old, serving also as a warning to workers and families of the consequences of having to become dependent on public programs.

Id. at 42 (citation omitted).

5. See McGlotten v. Connally, 338 F. Supp. 448, 456 (D.D.C. 1972) ("The rationale for allowing the deduction of charitable contributions has historically been that by doing so, the Government relieves itself of the burden of meeting public needs which in the absence of charitable activity would fall on the shoulders of the Government.").

6. Cf. Michael J. Graetz, The Troubled Marriage of Retirement Security and Tax Policies, 135 U. PA. L. Rev. 851, 856 \& n.11 (1987) (treating antipoverty and health insurance as separate issues from retirement security).

7. Deborah M. Weiss, Paternalistic Pension Policy: Psychological Evidence and Economic Theory, 58 U. CHI. L. Rev. 1275, $1275-76$ (1991).

8. For example, Social Security involves a redistributive element from higher-income to lower-income workers to the extent that lower-income workers receive a minimum benefit regardless of earnings history. See generally Kathryn L. Moore, Redistribution Under a Partially Privatized Social Security System, 64 Brook. L. Rev. 969 (1998) (noting that Social Security balances the "competing policy objectives [of] equity and social adequacy").

9. For example, employee benefit plans are subject to rules that proscribe discrimination in favor of highly compensated individuals, so that workers of all economic strata have retirement benefits. See generally Michael. J. Canan, Qualified Retirement Plans 112 (1999).

At the heart of qualified retirement plans is the concept that they cannot discriminate in favor of shareholders, officers, or highly compensated employees. The overall effect is that, within limits, a qualified retirement plan must offer the same benefits to officers, 


\section{nomic growth through increased savings rates. ${ }^{10}$}

\section{Current retirement security policies focus primarily on Social Secur-} ity and its private sector counterparts. Among these programs are private pensions and personal savings, which provide supplemental replacement income. ${ }^{11}$ Compulsory participation in Social Security ensures that nearly everyone contributes toward retirement security needs, which might otherwise have to be met through welfare programs. ${ }^{12}$ Although more than sixty percent of retirees rely on Social

\footnotetext{
shareholders, and highly compensated employees (members of the prohibited group) as are offered to the rank and file. Id.
}

10. Neoclassical economics assumes that increased savings rates, in the long run, produce increased standards of living. See Edward M. Gramlich, How Does Social Security Affect the Economy?, in Social Security in the 2 lst Century 147, 150 (Eric R. Kingson \& James H. Schulz, eds., 1997). Whether tax incentives have ultimately increased the national savings rate is debatable. See, e.g., Joint Committee on Taxation, JCT Staff Description (JCX-7-99) of Present Law and Background on Tax Incentives for Savings, reprinted in BNA DAILY TAX REPORT, February 25, 1999 ("Empirical investigations of the responsiveness of personal saving to after-tax returns provide no conclusive results."). However, tax incentives have clearly impacted the form in which retirement savings are held. Individual retirement accounts alone have grown from holding virtually no assets in 1980 to nearly $\$ 2$ trillion in assets in 1997. See 20 EBRI Notes 5 (May 1999) <http://www.ebri.org.notes/0599.htm>.

11. See, e.g., Graetz, supra note 6, at 853-54. Social Security also includes other social insurance aspects, such as survivor's and disability benefits. Other government programs, such as Medicaid, are designed to address medical needs of the poor. This article focuses only on replacement income for retirees.

12. See Joseph Bankman, Tax Policy and Retirement Income: Are Pension Plan Anti-Discrimination Provisions Desirable?, 55 U. CHI. L. Rev. 790, 815 n.97 (1988) (noting philosophical argument that Social Security is needed to avoid state support of the elderly); $i d$. at $820-21$ (noting forced saving as means of reducing government expenditures). Social Security retirement benefits are not means tested, so that even the wealthiest participants are entitled to benefits based on his or her earnings history. In this sense, Social Security is arguably consistent with ant-like values of work and savings, albeit in a cooperative context that relies on shared political commitments rather than private property rights. See Robert M. Ball \& Thomas M. Bethell, Bridging the Centuries: The Case for Traditional Social Security, in Social Security in the 21st CenTURy 259, 261 (Eric R. Kingson \& James H. Schulz, eds., 1997) ("Social Security emphasizes and reinforces the conservative values of work, saving, and self-help."). The view that Social Security benefits are "earned" is an important component of its political support. See Kathryn L. Moore, Privatization of Social Security: Misguided Reform, 71 Temple L. Rev. 131, 140-41 \& n.61 (1998). However, those "earned" benefits do not reach the status of property rights. See Fleming v. Nestor, 363 U.S. 603, 609-11 (1960), which states in part:

The 'right' to Social Security benefits is in one sense 'earned,' for the entire scheme rests on the legislative judgment that those who in their productive years were functioning members of the economy may justly call upon that economy, in their later years, for protection from 'the rigors of the poor house as well as from the haunting fear that such a lot awaits them when journey's end is near.' Helvering v. Davis, supra, 301 U.S. at page 641. But the practical effectuation of that judgment has of necessity called forth a highly complex and interrelated statutory structure. Integrated treatment of the manifold specific problems presented by the Social Security program demands more than a generalization. That program was designed to function into the indefinite future, and its specific provisions rest on predications as to expected economic conditions which 
Security benefits as their primary source of replacement income, ${ }^{13}$ most retirees require supplemental income in order to maintain preretirement living standards. ${ }^{14}$ Private pensions and retirement savings are often used to fill this income gap, thus providing an important complementary role in achieving retirement security goals. ${ }^{15}$

Tax law is the principal device used to implement government policies relating to private retirement savings. ${ }^{16}$ Some policies are based on inducing voluntary saving decisions. For example, by offering conditional opportunities to reduce income tax obligations, the government has attempted to induce retirement saving in special tax-favored plans. Nonsavers may shift from consumption to saving, ${ }^{17}$ or savers may shift the form of their savings into tax-favored vehicles in order to obtain tax benefits. ${ }^{18}$ Matching employer contributions available in

must inevitably prove less than wholly accurate, and on judgments and preferences as to the proper allocation of the Nation's resources which evolving economic and social conditions will of necessity in some degree modify.

To engraft upon the Social Security system a concept of 'accrued property rights' would deprive it of the flexibility and boldness in adjustment to everchanging conditions which it demands.

Id. at 610 .

13. See Senator Don Nickles, Retiring in America: Why the United States Needs a New Kind of Social Security for the New Millenium, 36 HARv. J. ON LEG1s. 77, 77 \& n.4 (1999).

14. Daniel I. Halperin, Tax Policy and Retirement Income: A Rational Model for the 21st Century, in Search for a National Retirement Income Policy 159, 161 \& n.13 (Jack L. VanDerhei, ed. 1987); Weiss, supra note 7, at 1284 ("The public component of retirement income, Social Security, is seldom adequate to provide income maintenance.").

15. See Michael S. Gordon, Introduction: The Social Policy Origins of ERISA, in EMPLOYEE Benefjts Law lxiii, Ixxi (Stephen J. Sacher, et. al., eds., 1991) (noting possibility that private pensions have flourished "because of Social Security's failure to prescribe more socially adequate benefits."); Halperin, supra note 14, at 159. Although some commentators have argued for an expanded government role in providing retirement income, recent reform proposals favoring privatization of a portion of Social Security suggest a limited political tolerance for that approach. For a critique of privatization, see generally Moore, Privatization of Social Security, supra note 12.

16. See, e.g., Graetz, supra note 6, at 854 ("tax legislation serves as the dominant public mechanism for implementing national retirement policy"); Bankman, supra note 12, at 793 ("[I]t is generally assumed that the growth and structure of private pension plans is in part a product of federal tax law."). For fiscal year 2001, the net exclusion for pension contributions and earnings for employer-provided plans is estimated to reduce tax receipts by $\$ 92.39$ billion, representing the largest tax expenditure in the federal budget. See Treasury Dep't General Explanation of Clinton Administration's Fiscal Year 2001 Revenue Proposals, and Excerpts from President Clinton's FY 2001 Budget Submitted to Congress Feb. 7, 2000, reprinted in BNA DaILY TAX REPORT, Feb. 8, 2000, at Table 5-3 (illustrating "[m]ajor Tax Expenditures in the Income Tax, Ranked by Total 2001 Revenue Loss").

17. Tax benefits presumably increase the perceived value of future consumption, as compared with current consumption. See Weiss, supra note 7 , at 1286-87. However, other psychological factors may also affect these decisions. See id. at 1300. See also Joint Committee on Taxation, supra note 10.

18. See infra Part II.C., for further discussion of these benefits. 
some retirement plans may provide an added incentive for employee participation. ${ }^{19}$

Other policies affecting employer-provided plans may effectively force employees to save, although they might prefer current consumption. ${ }^{20}$ For example, nondiscrimination and minimum participation requirements imposed on employers appear to harness some employees' voluntary preferences for tax-favored savings in order to broaden participation in retirement savings plans. ${ }^{21}$ In denying employees a choice to receive cash compensation in lieu of retirement benefits, and restricting access to retirement fund contributions, employer-funded plans may effectively require "grasshoppers" to save. ${ }^{22}$

Current law also provides tax-favored retirement saving options for self-employed business owners. Unlike an employee, an entrepreneur's choice to participate in a tax-favored plan is not limited by an employer's design. In this sense, the entrepreneur has greater discretion than an employee to choose and structure retirement savings. ${ }^{23}$ However, small business owners must also consider the competing need to increase business capital in evaluating the form of their investment. ${ }^{24}$ Prohibited transaction rules generally preclude small business

19. See infra note 138.

20. See Weiss, supra note 7 , at 1280.

21. See id.

22. Employers may also benefit from forcing employee participation in retirement savings plans. For example, an employer is allowed to defer vesting of pension benefits, which can be used to induce long-term employment commitments from employees. See I.R.C. $§ 411$ (1994 \& Supp. IV 1998).

23. See Richard J. Kovach, Tax Complexity, Regulatory Ambivalence, and Disparate Benefits and Burdens in Deferred Compensation Planning for Small Business, 11 St. Thomas L. Rev. 141, 141-42 (1998):

[E] arning a living as an employee who has no control over the employer, a situation shared by millions of American workers, allows very little flexibility for self-actuated deferred compensation planning. Aside from the privilege of making an annual contribution of only $\$ 2,000$ to an individual retirement account established personally, all possibilities for tax-favored deferred compensation savings reside solely within the discretion of employers. Those who earn their livings through self-employment become their own employers by technical designation and thus assume for themselves full discretion to implement qualified deferred compensation arrangements both for personal benefit and to enrich their common law employees ....

Id. at 141 (citations omitted).

24. See Jill R. Fisch, Can Internet Offerings Bridge the Small Business Capital Barrier?, 2 J. SMall \& Emerging Bus. Law 57, 58-62 (1998). Professor Fisch provides a particularly lucid and concise description of the travails of the entrepreneur in small business financing:

$[\mathrm{T}]$ he general economy is substantially affected by small business economics. At the same time, small businesses are critically dependent on adequate capital sources. "The chief cause of small business failures-after management error-is lack of capital." Traditionally, small businesses have had limited financing options. An entrepreneur typically funds the operations of a start-up company through a combination of personal 
owners from using capital in tax-favored retirement savings to satisfy business investment needs. ${ }^{25}$ Thus, an investment in tax-favored retirement savings is often an unrealistic choice for many small business owners, particularly during the start-up and growth phases of their businesses when capital formation demands are at their peak.

Investing outside of tax-favored retirement vehicles may also enhance retirement security. Equity in a small business can provide a source of supplemental retirement income. However, investing in a business, rather than a tax-favored retirement plan, generally places small business owners at a disadvantage. This is particularly true if they dispose of business assets in taxable transactions in order to provide supplemental income for retirement. ${ }^{26}$ This disadvantage potentially impacts their retirement security, serving to inhibit the efficient redeployment of business assets to the extent that taxable dispositions of those assets generate less favorable results than holding them until death. ${ }^{27}$

This article focuses on current policies affecting tax-favored retirement savings for small business owners. Part II provides an overview of tax-favored retirement savings options, and the wealth accumulation advantages of tax-favored saving. ${ }^{28}$ Part III discusses empirical data suggesting that many small business owners do not participate in tax-favored retirement saving; capital formation demands are a plausi-

funds and the contributions of friends and family members. Following the exhaustion of this seed money, the business must look to other capital sources.

Loans are one possible source of small business capital. Studies show that bank loans are the primary source of outside capital for small businesses. Nonetheless, small businesses often have difficulty qualifying for bank loans; they frequently lack the necessary collateral, operating history and proven track record. Economic fluctuations and changes in the banking industry may also create credit crunches that limit the amount of money available for small business loans. As a result, although bank loans are critical to small businesses, small businesses receive only a small share of the credit available to U.S. companies. Those businesses that are successful in obtaining bank financing are most likely to be those in which the owners have sufficient personal wealth to provide personal guarantees or collateral as security.

Bank loans may also be a problematic capital source for small businesses. The cash flow demands of debt financing can be burdensome and may limit the opportunity for growth through reinvestment of earnings. Businesses may be unable to meet interest obligations during periods of economic uncertainty. Finally, the traditional conservatism of bank loan officers may be incompatible with the risks of entrepreneurship. Loan terms that allow a bank to block risky projects or ambitious expansion may cripple business development.

Id. at 59-61 (citations omitted).

25. See infra section IV.

26. See infra section IV.B.

27. See infra section IV.C.

28. See infra section II. 
ble explanation for such nonparticipation. ${ }^{29}$ Part IV discusses tax features affecting the lifecycle of a small business. ${ }^{30}$ For instance, capital investments and dispositions of business property illustrate the disadvantages of investing outside of tax-favored accounts. Finally, Part V provides suggestions for reform, which include: (1) expanding the options to access funds from tax-favored plans; (2) changing the income base for contributions to tax-favored plans to include gains from the sale of business property; and (3) allowing additional contributions to tax-favored plans up to a defined maximum balance for those transitioning to retirement. ${ }^{31}$

\section{Overview of Tax-Favored Retirement Savings}

From the perspective of neoclassical economics, a decision to save is a function of the comparative utility of current or deferred consumption. ${ }^{32}$ Thus, the decision is akin to a consumer's choice of one good over another, requiring a personal calculus of the comparative benefits of each alternative. ${ }^{33}$ Although our society generally values and protects individual choices in consumption patterns, tax law has emerged as a means to influence this calculus for retirement savings. ${ }^{34}$ Tax-qualified savings vehicles, such as employer-provided pensions, Individual Retirement Accounts (IRAs), and Keogh plans, receive tax-favored treatment that create a powerful advantage in wealth accumulation. ${ }^{35}$ However, conditions on tax-favored status also create barriers to participation that may be particularly troublesome for small business owners. ${ }^{36}$

\section{A. Timing Principles for Income and Deductions}

The proper time for including income or taking into account liability for income tax purposes is an important issue to both taxpayers and the government. ${ }^{37}$ General principles governing the timing of income and deductions that apply outside of tax-qualified retirement

29. See infra section III.

30. See infra section IV.

31. See infra section $\mathrm{V}$.

32. See Weiss, supra note 7 , at $1285-88$.

33. See id.

34. See id. See also Hon. Bill Bradley, Economic Security in Retirement: Whose Responsibility? in Search for a National Retirement Income Policy 1, 5-9 (Jack L. VanDerhei, ed. 1987).

35. See infra Part II.C.

36. See infra Part II.D.

37. Cf. Peracchi v. Commissioner, 143 F.3d 487, 490 (9th Cir. 1998) ("In tax, as in comedy, timing matters."). 
plans are helpful in establishing a benchmark to evaluate the nature and extent of tax preferences applicable to tax-qualified retirement plans.

\section{Income}

Section 451 of the Internal Revenue Code (Code) provides the following general rule for the year in which income is taken into account: "The amount of any item of gross income shall be included in the gross income for the taxable year in which received by the taxpayer, unless, under the method of accounting used in computing taxable income, such amount is to be properly accounted for as of a different period." 38 This provision indicates that taxation upon receipt is the default rule, though receipt does not always govern the time for taxation. The taxpayer's accounting method is essential to resolving this question of timing.

For accrual method taxpayers, "income is includable in gross income when all the events have occurred which fix the right to receive such income and the amount thereof can be determined with reasonable accuracy." 39 In focusing on the right to receive, rather than actual receipt of cash or other property, an accrual method taxpayer may be required to take income into account before receiving payment. ${ }^{40}$ Since a right to receive income is likely to have value before it is reduced to cash, the resulting measure of income is closer to the classical Haig-Simons approach than a method focusing only on actual receipt. ${ }^{41}$

For cash method taxpayers, which include virtually all employees, regulations clarify that income is recognized in the year of "actual or constructive receipt." 42 Unlike the accrual method, an unsecured

38. I.R.C. § 451(a) (1994).

39. Treas. Reg. $\$ 1.451-1$ (a) (as amended in 1993).

40. See Knight-Ridder Newspapers, Inc. v. United States, 743 F.2d 781 (11th Cir. 1984) (Under the accrual method, "[t]ransactions producing income ... spring to life in the eyes of the seer though nary a dollar has moved.").

41. See Daniel I. Halperin, Interest in Disguise: Taxing the "Time Value of Money," 95 YALE L. J. 506, 508-09 (1986) ("Haig-Simons definition . . suggests that all changes in asset value should be taken into account as they occur."); $i d$. at 506-07 (noting that accountants and economists view accrual as "the proper standard in principle" in answering the question of timing). Although the cash method is widely used, it should be noted that it does not conform to generally accepted accounting principles (GAAP). See American Fletcher Corp. v. United States, 832 F.2d 436, 439-40 (7th Cir. 1987); H.R. REP. No. 99-426, at 604-05 (1985) (containing the House Committee on Ways \& Means report on the Tax Reform Act of 1983 to the Committee of the Whole House on the State of the Union).

42. Treas. Reg. $§ 1.446-1$ (c)(1)(i) (as amended in 1997); $\$ 1.451-1$ (a) (as amended in 1993). As a technical matter, constructive receipt may also apply to accrual basis taxpayers, such as in determining whether actual receipt has occurred in the case of a taxable advance payment. See 4 
promise to pay is not a sufficient basis to recognize income under the cash method. ${ }^{43}$ Regulations explain the constructive receipt concept as follows:

Income although not actually reduced to a taxpayer's possession is constructively received by him in the taxable year during which it is credited to his account, set apart for him, or otherwise made available so that he may draw upon it at any time, or so that he could have drawn upon it during the taxable year if notice of intention to withdraw had been given. However, income is not constructively received if the taxpayer's control of its receipt is subject to substantial limitations or restrictions. ${ }^{44}$

The constructive receipt doctrine developed as a method to ensure that taxpayers could not simply defer taxable income at will. ${ }^{45}$ As a result, "[w]hen compensation for services is due and payable, a taxpayer cannot defer recognition of the income by requesting the employer, customer, or client to delay payment or to place the funds in an escrow or other account to be paid out at a later time." 46 However, constructive receipt may be avoided if the payor imposes restrictions on the right to receive income before that right accrues, and the payee does not initiate these restrictions. ${ }^{47}$ Thus, it may be possible to defer taxation beyond the period in which income is earned if access to that income is restricted.

\section{Deductions}

Section 461 of the Code sets forth a cryptic rule which states that liabilities are taken into account for "the proper taxable year under the method of accounting used in computing taxable income." 48 For cash method taxpayers, this rule generally means that expenditures giving rise to deductions are taken into account in the taxable year

Boris I. Bittker \& Lawrence Lokken, Federal Taxation of Income, Estates, and Gifts II 105.3.3, at 105.51 \& n.21 (2nd ed. 1992).

43. See Rev. Rul. 60-31, 1960-1 C.B. 174, modified by Rev. Rul. 64-279, 1964-2 C.B. 121, and Rev. Rul. 70-435, 1970-2 C.B. 100

44. Treas. Reg. §1.451-2(a) (as amended in 1979).

45. Stephen F. Gertzman, Federal Tax Accounting II 3.02[2][b], at 3-22 (1998).

46. $1 d$.

47. See id. As a practical matter, the Commissioner has taken the position that it will not speculate whether an employer would have agreed to pay compensation without imposing a restriction. See Rev. Rul. 60-31, 1960-1 C.B. 174 ("the statute cannot be administered by speculating whether the payor would have been willing to agree to an earlier payment.") This approach eliminates the practical question of whether an employee bargained for a condition for purposes of constructive receipt.

48. I.R.C. $\S 461$ (a) (1994). 
when paid. ${ }^{49}$ Payment may occur through cash, checks, or other property, but the taxpayer's own note is generally not considered payment; a mere promise to pay in the future is not a sufficient basis for a deduction by a cash method taxpayer..$^{50}$

For an accrual method taxpayer, regulations provide the following basic requirements for taking into account a liability:

Under an accrual method of accounting, a liability ... is incurred, and generally taken into account for Federal income tax purposes, in the taxable year in which all the events have occurred that establish the fact of liability, the amount of the liability can be determined with reasonable accuracy, and economic performance has occurred with respect to the liability. ${ }^{51}$

This all-events test, which includes a so-called "economic performance" requirement, limits the accrual method taxpayer's ability to take into account liabilities in advance of payment. ${ }^{52}$ The economic performance rules are implemented through regulations that seek to identify those circumstances where it is proper to permit accrual prior to payment. ${ }^{53}$ For example, if a fixed liability relates to services provided to the taxpayer, economic performance occurs as those services are provided, even though actual payment may occur later. ${ }^{54}$

\section{Application to Deferred Compensation (Non-Qualified Plans)}

The general principles discussed previously indicate that when an employer places funds in an unrestricted account for the purpose of compensating an employee, that employee clearly has income in the year those funds are made available. ${ }^{55}$ In such circumstances, an employee obtains either cash or a property right that is equivalent to cash, ${ }^{56}$ making taxation appropriate under either cash or accrual

\footnotetext{
49. Treas. Reg. \$ 1.461-1(a) (as amended in 1994). See Gertzman, supra note 45, II 3.04[5], at 3-34 (discussing this general rule and numerous exceptions).

50. See Gertzman, supra note 45, II 3.04[4], at 3-32.

51. Treas. Reg. $\$ 1.461-1(a)(2)$ (i) (as amended in 1994). See GertzMAN, supra note 45, II 4.04, at 4-35 for further exposition of these requirements.

52. The term "liability" includes both deductible expenses and capitalized costs. See Treas. Reg. $\S 1.446-1$ (c)(1)(ii)(B) (as amended in 1997).

53. See Treas. Reg. \$§ 1.461-4,-5 (as amended in 1995).

54. See Treas. Reg. $\$ 1.461-4(d)(6)(i)$ (as amended in 1995). Certain other exceptions may apply, such as provisions for recurring items, which further complicate this analysis. See Gertzman, supra note 45, II 4.04[3][f], at 4-58.

55. See Gertzman, supra note 45, II 3.03[3][c], at 3-27. Courts have held that notice is not required; the mere existence of a right to access is determinative. See id.

56. See id. Section 83 of the Code contains specific rules governing the taxability of the receipt of property. However, unfunded deferred compensation is not covered by section 83 , as there has been no transfer of property. See Treas. Reg. \$1.83-3(e) (as amended in 1985) ("For purposes of section 83 and the regulations thereunder, the term "property" includes real and
} 
methods. ${ }^{57}$ Moreover, the employer may take this payment into account as a deduction in the current year, ${ }^{58}$ provided that capitalization is not required. ${ }^{59}$

However, by imposing restrictions on access to payment, a deferred compensation arrangement could potentially allow cash method employees to defer taxation until cash is received, even though compensation has been earned. For example, suppose that on January 1, year one (Y1), an employer agrees to pay an employee $\$ 10 \mathrm{x}$ on January 1 , year two (Y2), for services performed during Y1. Assume further that the employer's promise is unsecured and contingent on performance of services during Y1, but the right to payment is otherwise not forfeitable. The employee completes the required services during Y1, and thus becomes entitled to payment.

An accrual basis taxpayer performing these services would recognize $\$ 10 \mathrm{x}$ of income in Y1. In this situation, the promise to pay satisfies the all-events test once the services have been completed, and thus income must be taken into account prior to actual receipt. 60 However, for a cash method taxpayer, the Internal Revenue Service (Service) has ruled under similar facts that income recognition is deferred until receipt of the cash payment. ${ }^{61}$ Even though the cash method taxpayer may have a valuable right (assuming that the employer is creditworthy), this unsecured promise does not satisfy the requirements of constructive receipt. ${ }^{62}$ The hypothetical possibility that the employer may have agreed to pay this compensation before the year Y2 does not change the result because the Service has ruled that "the statute cannot be administered by speculating whether the payor would have been willing to agree to an earlier payment." 63

With respect to the payor's treatment, a cash-method employer would not be permitted to deduct the compensation until Y2, when it

personal property other than either money or an unfunded and unsecured promise to pay money or property in the future." (emphasis added)).

57. See Felicia D. Brown, Note, Nonqualified Deferred Compensation Plans and Constructive Receipt: Martin v. Commissioner, 45 TAX LAw. 635, 644-45 (1992).

58. See I.R.C. $\$ 162(a)$ (1994 \& Supp. IV 1998) (allowing deduction for "ordinary and necessary expenses paid or incurred during the taxable year in carrying on any trade or business, including .... a reasonable allowance for salaries or other compensation for personal services actually rendered").

59. Otherwise deductible compensation may be subject to capitalization requirements. See GERTZMAN, supra note 45, II 6.06[2][c], at 6-40 (discussing capitalization of deferred compensation as an inventoriable cost).

60. See Treas. Reg. $\$ 1.451-1$ (a) (as amended in 1993).

61. See Rev. Rul. 60-31, supra note 43.

62. See id.

63. See id. 
was paid. An accrual method employer could potentially satisfy the general principles for accrual outlined above. However, Congress has enacted a special rule precluding such an accrual before the employee includes the amount in income. ${ }^{64}$ This provision has the effect of placing employers on the cash method with respect to deferred payments. ${ }^{65}$ As a result, the provision prevents timing differences between the employer's deduction and the employee's receipt of income, which could detrimentally effect the United States Treasury. ${ }^{66}$

While the above example involves an unfunded and unsecured promise, different rules may apply if the employer funds a trust to secure a promise of deferred compensation. Assume that the employer in the example discussed above deposits funds into an irrevocable trust for the benefit of the employee. Assume further that trust benefits are accessible by the employee only after normal retirement age, and the employee's interest in the trust is not otherwise forfeitable. The employee has received a valuable property right in the trust, which differs from an employer's unsecured promise. However, whether this right is sufficient to satisfy the requirement of constructive receipt is an open question. ${ }^{67}$ Congress enacted a special rule to deal with the uncertainty of such circumstances. Section 404(b)(1) of the Code requires that contributions to a trust, that are not otherwise exempt, ${ }^{68}$ are taxable to the employee using principles similar to those under section 83.69 Thus, the employee would be taxed based on the fair market value of the vested interest in the employer's contribution. ${ }^{70}$ As with an unfunded promise, the special rule of section 404(a)(5) governs the timing of the employer's deduction, effectively

64. See I.R.C. $\S 404(a)(5)$ (1994). For a discussion of the history and interpretation of this provision, see 2 BITTKER \& LOKKEN, supra note 42, Tा 60.2, at 60-15.

65. See Treas. Reg. $\$ 1.404$ (a)-1(c) (as amended in 1963).

66. As Professor Halperin has pointed out, deferring a deduction for the payor may be an alternative, equivalent approach to taxing the recipient. See Halperin, Interest in Disguise, supra note 41 , at 519-20.

67. In particular, the concern would be whether the property rights constituted a cash equivalent. See 4 BiTrker \& LoKken, supra note 42, II 105.3.2, at 105-48 (noting inconsistency in judicial approaches to resolving cash equivalency problems); GerTzMAN, supra note 45 , $\mathbb{1}$ $3.03[1][\mathrm{d}]$, at 3-15 (noting the same effect).

68. See infra Part II.B.1 for a discussion of exempt trusts under tax-qualified plans.

69. See I.R.C. $\$ 404$ (b)(1) (1994). As in section 83, the fair market value of rights acquired can be taken into account when such rights are either transferable or free from a substantial risk of forfeiture. See 2 BitTKer \& Lokken, supra note 42, \$ 60.3, at 60-26.

70. See 2 Bitrker \& Lokken, supra note 42, If 60.3, at 60-26. Certain highly compensated employees may even be taxed on the total increase in the value of vested accrued benefits, not just on the annual contribution. This represents a penalty designed to discourage non-exempt trusts, particularly when highly compensated employees are beneficiaries. See id. 
matching the deduction to the period in which the employee recognizes income. ${ }^{71}$

Using a trust as a funding vehicle also presents additional complexity concerning taxation of trust income and distributions. Alternative tax treatments of trust income are theoretically possible. For example, the trust could be taxed as a separate entity, ${ }^{72}$ or the employee could be taxed under rules similar to those applicable to grantor trusts. $^{73}$ However, the Code imposes tax on the non-exempt trust, specifically denying grantor trust treatment to the beneficiary. ${ }^{74}$ Trust income over $\$ 8,350$ is taxed at 39.6 percent, ${ }^{75}$ while this rate applies only to taxable incomes over $\$ 278,450$ for other individual taxpayers. ${ }^{76}$ Thus, trust taxation is generally disadvantageous to those with marginal tax rates of less than 39.6 percent.

Special rules also apply to distributions that are even more disadvantageous to the beneficiary. Under general principles of trust taxation, beneficiaries of complex trusts receiving distributions of income that had been previously accumulated and taxed to a trust are not taxed on such distributions. If the beneficiaries are taxed, they will receive a credit for tax previously paid by the trust. ${ }^{77}$ Thus, distributed income is taxed only once, with potential adjustments occurring in limited circumstances to ensure that the trust was not used to obtain a lower tax rate than otherwise applicable to the beneficiary. ${ }^{78}$

71. See I.R.C. $\$ 404(\mathrm{a})(6)(1994)$.

72. See I.R.C. $\$ 641$ (1994 \& Supp. IV 1998).

73. See generally 1.R.C. $\$ \S 671-677$ (1994 \& Supp. IV 1998). It may also be appropriate to tax trust income to the employer, to the extent that the employer, not the employee, is deemed to be the beneficial owner. See Minor v. United States, 772 F.2d 1472, 1475 (9th Cir. 1985).

74. See I.R.C. \$ 402(b)(3) (1994). See 2 BITTKER \& LoKkEN, supra note 42, If 60.3, at 60-26.

75. See I.R.C. $\$ 1$ (e) (1994), as adjusted for inflation through 1998, in Rev. Proc. 97-57, 1997 52 I.R.B. 20.

76. See I.R.C. $\$ 1$ (a) (1994) (married individuals filing joint returns); § 1(b) (1994) (heads of households); $\$ 1$ (c) (1994) (unmarried individuals), as adjusted for inflation through 1998, in Rev. Proc. 97-57, 1997-52 I.R.B. 20.

77. See John R. Price, Price on Contemporary Estate Planning $§ 10.4 .10$ (1992) (summarizing "throwback rules" under I.R.C. $\$ \$ 665-667$ affecting distributions from complex trusts). These "throwback rules" were effectively repealed for most domestic trusts by the Taxpayer Relief Act of 1997, which enacted current 1.R.C. $\$ 665(\mathrm{c})$. However, these "throwback rules" may still apply to certain domestic trusts created before March 1, 1984 and foreign trusts. See I.R.C. $\$ 665$ (c) (1994 \& Supp. IV 1998).

78. See PrICE, supra note 77, at $\$ 10.4 .10$. As Price points out, the rate arbitrage that gave rise to the throwback rules was substantially curtailed by lowering individual tax rates. Raising tax rates applicable to trusts further eliminates this potential for tax abuse, thus giving rise to the exemption for domestic trusts in current I.R.C. $\$ 665(\mathrm{c})$. See CCH, TAXPayer Relief Act of 1997: LAW AND ExpLANATION II 275, at 204 (1997). 
Section 402(b)(2) of the Code requires these trust distributions to be taxed by applying the principles that are applicable to annuities, ${ }^{79}$ however, the Code does not take into account taxes previously imposed on the trust. ${ }^{80}$ Although the beneficiary is allowed to recover a portion of each distribution tax free, this portion is limited to the amounts previously taxed to the beneficiary, not to the trust. ${ }^{81}$ Thus, accumulated trust earnings that were taxed once to the trust are effectively taxed again upon distribution. This method has a distinct disadvantage as compared to general tax principles applicable to trusts. ${ }^{82}$

\section{B. Principles Governing Tax-Favored Retirement Savings: Employer-Sponsored Qualified Plans, Individual Retirement Accounts, and Keogh Plans}

Tax-favored retirement savings plans, including employer-provided qualified retirement plans, individual retirement accounts, and Keogh plans, provide opportunities to achieve tax benefits that are otherwise unavailable under the general principles discussed above. However, these tax benefits are conditioned upon compliance with various provisions designed to implement retirement security policies. As discussed below, the particular conditions vary, since each savings vehicle reflects a patchwork approach rather than a seamless web of protection for retirees.

\section{Employer-Sponsored Qualified Retirement Plans}

A "qualified plan" generally refers to a pension, profit-sharing, stock bonus, or annuity plan utilizing a trust that meets the requirements of section 401(a) of the Code..$^{83}$ Stated very generally, section 401(a) requires a domestic trust ${ }^{84}$ for the exclusive benefit of employees or their beneficiaries. ${ }^{85}$ The trust must also meet other requirements, including minimum participation standards ${ }^{86}$ and compliance with rules prohibiting discrimination in favor of highly compensated

\footnotetext{
79. See I.R.C. \& 72 (1994 \& Supp. IV 1998).

80. See I.R.C. $\$ 402(b)(2)$ (1994). See 2 BitTKer \& LoKken, supra note 42, 9l 60.3, at 60-26.

81. See 2 BitTKer \& LoKKen, supra note 42, II 60.3, at 60-26.

82. See id.

83. See id. II 61.2, at 61-16. See also CanAN, supra note 9, § 1.6[D]

84. See I.R.C. § 401(a) (1994 \& Supp. IV 1998) (referring to "trust created or organized in the United States").

85. See I.R.C. § 401(a)(2) (1994) (requiring impossibility for "any part of the corpus or income to be ... used for, or diverted to, purposes other than the exclusive benefit of his employees or their beneficiaries"). Congress imposed this requirement in 1938 in response to perceived employer abuses of tax-favored pension trusts. See EMPLOYEe BENEFITS LAW, supra note 15, at 71. 86. See I.R.C. $\S 401(a)(3)$ (1994) (imposing minimum participation requirements of I.R.C. $\S 410$ ).
} 
employees. ${ }^{87}$ Additionally, the trust needs to comply with certain other conditions designed to protect beneficiaries and insure that funds will be used to provide retirement benefits. ${ }^{88}$

In contrast to the nonqualified deferred compensation trusts discussed above, both employers and employees potentially benefit from tax-qualified status. First, employees are eligible to defer taxation on employer contributions until the taxable year in which distributions occur. ${ }^{89}$ These amounts would otherwise be taxable to employees when they received a vested right in the trust which is likely to occur before distributions begin. ${ }^{90}$ Second, employers are eligible to take these contributions into account during the current year, ${ }^{91}$ rather than deferring them until employees include a corresponding amount in their taxable income. ${ }^{92}$ Third, a qualified trust is exempt from taxation on its income; ${ }^{93}$ such income is taxed to beneficiaries upon distribution. ${ }^{94}$ As discussed below, although only tax deferral is apparent from this scheme, this deferral potentially results in an exemption from taxation for investment income, which provides a powerful incentive for participation. ${ }^{95}$

Qualified retirement plans can be categorized as defined benefit or defined contribution plans. Defined benefit plans involve a commitment to provide employees with predetermined retirement benefits. ${ }^{96}$ Under current law, defined benefits may not exceed the lesser of $\$ 130,000$ or a participant's average compensation for his "high 3 years" of employment. ${ }^{97}$ Employers are obligated to contribute the

87. See I.R.C. $\$ 401(a)(4)$ (1994) (prohibiting discrimination in favor of highly compensated employees as defined in I.R.C. \$ 414(q)).

88. See 2 BittKer \& Lokken, supra note 42, II 61.2, at 61-16.

89. See I.R.C. $\$ 402$ (a)(1) (1994). Additional deferral may be allowed when a nontransferable annuity contract is distributed from a qualified plan. See 2 BITTKER \& LOKKEN, supra note 42, II 61.13.1, at 61-151. Distributions from a qualified plan may also be rolled over into an IRA, which can defer taxation until distributions are made from the IRA. See I.R.C. § 402(c) (1994).

90. See supra notes 62-66 and accompanying text.

91. See I.R.C. $\$ 404(a)(1)$ (1994 \& Supp. IV 1998). Deductions are subject to the general limitations on reasonable compensation in sections 162 and 212 of the Code. See Treas. Reg. $\$ 1.404(\mathrm{a})-1$ (b) (as amended in 1963). Applicable capitalization requirements must also be taken into account, as when employer contributions involve labor engaged in inventory production. See I.R.C. $\$ 263$ A (1994). Other limitations may also apply, such as limitations on excess contributions. See infra Part II.D.

92. See supra note 66 .

93. See I.R.C. $\$ 501$ (a) (1994).

94. See I.R.C. \& 404(a)(1) (1994 \& Supp. IV 1998).

95. See infra Part II.C.

96. See Treas. Reg. $\$ 1.401-1$ (b)(1)(i) (as amended in 1976). Certain other benefits, such as payment upon disability, may also be included among "retirement" benefits. See id.

97. See I.R.C. $\$ 415$ (b)(1) (1994 \& Supp. IV 1998). The $\$ 90,000$ figure stated in $\S 415(\mathrm{~b})(1)(\mathrm{A})$ is subject to annual cost-of-living adjustments. See I.R.C. $\$ 415(\mathrm{~d})(1994)$. The 
actuarially determined costs of providing the benefits prescribed in the plan documents. ${ }^{98}$ Thus, employers bear the responsibility of ensuring that trust assets are adequate to satisfy those future benefit commitments. ${ }^{99}$ Regulations governing pension funding and investment are designed to reduce the risk of default to employees. ${ }^{100}$ Federally provided insurance protection from the Pension Benefit Guaranty Corporation (PBGC) is designed to provide additional security for participants in the event of default. ${ }^{101}$

In a defined contribution plan, the employer's obligation extends only to making specified contributions, which are allocated to separate accounts for each participant. ${ }^{102}$ Current law generally allows a maximum contribution of 25 percent of compensation or $\$ 30,000$, whichever is less. ${ }^{103}$ Retirement benefit levels ultimately depend on the contributions and earnings accumulated for each participant's account. In this way, employees bear investment risks associated with planning for their expected retirement needs. ${ }^{104}$ Defined contribution plans may also allow self-directed investments, which impose further responsibility on employees for their retirement security. ${ }^{105}$ Superior investment performance could result in a windfall, but poor performance could leave the employee disappointed and insecure at retirement.

applicable figure for 1999 is $\$ 130,000$. See Notice 98-53, 1998-46 I.R.B. 24. The "high 3 years" is defined in I.R.C. $\$ 415$ (b)(3). Failure to comply with this benefit limitation disqualifies the trust. See I.R.C. $\$ 401(a)(16)$ (1994). Adjustments to these limitations may apply, such as when pension benefits begin either before or after the social security retirement age. See I.R.C. $\S 415$ (b)(2)(C) \& (D) (1994 \& Supp. IV 1998).

98. See I.R.C. $\$ 415$ (b) (1994 \& Supp. IV 1998).

99. See 2 BitTKER \& LoKKen, supra note 42, If 61.1.3, at 61-151.

100. See generally James H. Smalhout, The Uncertain Retirement 7-13 (1996) (discussing origins of ERISA protections).

101. See id. However, Smalhout points out that in 1990 , only 16.9 percent of the total workforce was covered by this insurance. Id. at 13 .

102. See I.R.C. \$ 414(i) (1994). For example, contributions may be defined as a percentage of compensation, or in a profit sharing plan, as a percentage of corporate profits. See CaNan, supra note 9 , at $\$ 3.111[\mathrm{~A}]$.

103. See I.R.C. $\$ 415$ (c) (1994 \& Supp. IV 1998). However, practical constraints, such as nondiscrimination provisions, may limit the ability to contribute the maximum amount in particular cases. See 2 BitTKER \& LOKKEN, supra note 42, ग 61.4, at 61-154; CANAN, supra note 9, at $\$ 10.4$.

104. See CANAN, supra note 9 , at $\$ 3.111[\mathrm{G}]$. Federal insurance protection from the PBGC is not available for defined contribution plans. See 19 U.S.C. $\$ 1321$ (b) (1994) (exempting coverage for "individual account plans"). Although defined contribution plans avoid administrative costs associated with PBGC insurance premiums, the lack of coverage emphasizes that the locus of risk bearing is on the employees.

105. A detailed discussion of fiduciary obligations is beyond the scope of this article. However, even participant-directed investments in individual account plans do not completely eliminate fiduciary obligations. See Canan, supra note 9 , at $\$ \$ 16.03$ to .04 . 
Some commentators prefer defined benefit plans as the most effective means of meeting retirement security goals, based in part on the assumption that employers are better able to deal with the risks associated with providing adequate retirement benefits. ${ }^{106}$ Nevertheless, employers are increasingly utilizing defined contribution plans. ${ }^{107}$ This trend may be due to such factors as the cost and administrative complexity associated with defined benefit plans, and an aversion to risks associated with meeting defined benefit commitments over potentially drawn out time-frames. ${ }^{108}$

Defined contributions plans are not immune from problems of administrative complexity and costs. Congress addressed this problem in the Revenue Act of $1978,{ }^{109}$ by enacting a simplified form of defined contribution plan known as a Simplified Employee Pension (SEP). ${ }^{110}$ The Senate Finance Committee Report explained the reason for providing this new retirement savings vehicle as follows:

The committee is aware that many qualified pension plans have been terminated in the recent past due, in part, to the complex and burdensome rules they are required to satisfy. The committee believes that these rules have also had the effect of retarding the introduction of new pension plans. The committee is concerned that, because of the expense and effort required to comply with present rules for tax qualified plans, many employees, particularly the employees of small businesses, will not earn employer-provided retirement benefits. ${ }^{111}$

Rather than using a tax-exempt trust, the SEP uses an Individual Retirement Account (IRA) for each employee as the vehicle to

106. See, e.g., Graetz, supra note 6 , at 892 . However, it should be noted that in times of extraordinarily positive market performance, employees in defined contribution plans reap benefits otherwise retained by employers in defined benefit plans, which are subject to reversion by the employer. For a discussion of reversions from defined benefit trusts, see 2 BITTKer \& LoKKEN, supra note 42, I 61.13, at 61-151.

107. See, e.g., Smalhour, supra note 96, at 11-12. Traditional, defined benefit plans have decreased from $\$ 103,346$ in 1975 to only $\$ 53,000$ in 1997. See Rebecca Adams, Pension Rewrite Handcuffed to Dead-End Tax Cut Bill, 57 C.Q. WeEkLY 2004 (1999) (reporting data from Employee Benefits Research Institute).

108. See Smalhout, supra note 100 , at 12; Halperin, supra note 14, at 186-90. See also Canan, supra note 9 , at 252.

Typically, a defined benefit plan is subject to more administrative burdens than a defined contribution plan, because of the necessity of calculating continuing employer contributions and because of additional reporting and compliance requirements. It also has the cost of Pension Benefit Guaranty Corporation (PBGC) premiums. With a plan covering 100 or more employees, the additional burden may not be significant; however, a small employer may find the additional compliance cost substantial.

109. See Revenue Act of 1978, Pub. L. No. 95-600, 92 Stat. 2763, § 152 (1978).

110. See id.

111. S. Rep. No. $95-1263$, at 92 (1978). 
achieve tax-favored retirement saving. ${ }^{112}$ The IRA essentially relieves the employer from fiduciary obligations otherwise associated with plans involving trusts. ${ }^{113}$ Moreover, employers may use a simplified form to adopt a model SEP, which contains all applicable requirements and avoids special document preparation. ${ }^{114}$

Under present law, employers may contribute up to 15 percent of compensation, with a maximum of $\$ 24,000$, to an employee's SEPIRA. ${ }^{115}$ These contributions are excludable from the employee's taxable income, ${ }^{116}$ while distributions are included in taxable income pursuant to general provisions governing IRAs. ${ }^{117}$ Contributions need not be made every year. When contributions are made, it must be pursuant to a written allocation formula. ${ }^{118}$ Moreover, the contributions must include all employees age twenty-one and over, who performed services during at least three of the five previous years, and who have received at least $\$ 400$ in compensation from the employer during the current year. ${ }^{119}$ Although benefits in other defined contribution plans may be subject to deferred vesting requirements, SEP provisions require full vesting for all contributions. ${ }^{120}$

112. IRAs are discussed further in infra part II.C.2.

113. See Individual Retirement Plans Guide (CCH) 92280 (1999).

114. For a more detailed discussion of requirements for establishing a SEP and the limitations of Model SEPs adopted using Form 5305-SEP, see id. Iㅔ 2260, 2350. See also CANAN, supra note 9 , at $\S 4.8[\mathrm{D}]$ (discussing reports and forms required for SEPs).

115. See I.R.C. $\$ 402(\mathrm{~h})(2)(1994)$. This is considerably more than the $\$ 2,000$ limit presently applicable to IRAs. See I.R.C. $\$ 219($ b $)(1)(A)$ (1994). It should be noted that section 415 (c)(1)(A) provides a general limitation of 25 percent of compensation or $\$ 30,000$ for defined contribution plans, while the special rules for SEPs in $402(\mathrm{~h})(2)$ provide a limitation of only 15 percent. Further, section $408(\mathrm{k})(3)(\mathrm{C})$ precludes contributions based on salaries greater than $\$ 150,000$, as indexed for inflation. See I.R.C. $\$ 408(k)(8)(1994)$. This figure is now $\$ 160,000$. See Notice $98-53,1998-46$ I.R.B. 24. Thus, until the salary limit in $408(k)(3)(C)$ increases to $\$ 200,000$, the maximum contribution limitation for a SEP will be less than the $\$ 30,000$ maximum for other qualified defined benefit pension plans.

116. See I.R.C. $\$ 402(\mathrm{~h})(1)(1994)$. Employer contributions are not subject to FICA and FUTA taxes. See I.R.C. \$§ 3121(a)(5) (1994 \& Supp. IV 1998) (FICA), 3306(b)(5) (1994 \& Supp. IV 1998) (FUTA).

117. See I.R.C. $\$ 402(h)(3)$ (1994). SEP provisions require that employees be allowed to withdraw funds from their SEP-IRAs at any time. See I.R.C. $\$ 408(k)(4)$ (1994). However, such withdrawals are still subject to income taxes and potential penalty taxes in some circumstances. These tax consequences are discussed in infra part II.D.2.

118. See I.R.C. $\$ 408(k)(5)(1994)$. Proposed regulations indicate that this formula may be varied from year to year. See Prop. Treas. Reg. $\$ 1.408-7(\mathrm{e})(2)$.

119. See I.R.C. $\$ 408(k)(3)(1994)$. The $\$ 300$ compensation limit stated in section $408(k)(3)$ is currently $\$ 400$ as adjusted for inflation. See I.R.S. Notice $98-53,1998-46$ I.R.B. 24 . It should be noted that this three year requirement is more generous toward employers than other pension plans, which typically require participation after only one or two years service. See INDIVIDUAL Retirement Plans Guide, supra note 113, at $\mathbb{1} 2270$.

120. See I.R.C. $\$ 408(k)(4)$ (1994) (employee withdrawals must be permitted). 
The various pension options discussed above are funded primarily with employer contributions. Realistically speaking, the employerfunded plans tend to force some employees to save for retirement, despite the fact that they might otherwise prefer to receive the employer's contribution as cash compensation. ${ }^{121}$ However, another employer-provided plan known as a "cash or deferred arrangement" (CODA), or "401(k) plan," accommodates greater flexibility for employee discretion in participation. This feature has apparently been popular, since CODAs have contributed significantly to growth in qualified plan participation during the past two decades. ${ }^{122}$

Under a CODA, employees have the option of receiving cash compensation or contributing it to a qualified trust. ${ }^{123}$ Although the constructive receipt doctrine would arguably require taxation to the employee, the Code permits these contributions to be made with pretax dollars in much the same manner as employer contributions to qualified pensions. ${ }^{124}$ Thus, employees are not taxable on the amounts they contribute, and accumulated earnings are not taxed until distribution. ${ }^{125}$ Employers are permitted, but not required, to match employee contributions, subject to certain limitations designed to ensure that matching contributions do not discriminate in favor of highly compensated employees. ${ }^{126}$

By allowing deductible voluntary employee contributions, CODAs are treated more favorably than other qualified pension plans. ${ }^{127}$ Qualified pension plans other than CODAs frequently fail to allow employee contributions. If contributions are allowed, they are nondeductible, although the earnings on such contributions are tax-exempt until distribution. ${ }^{128}$ However, CODAs are subject to more stringent

121. See infra Part II.D.1.

122. See Jack VanDerhei et. al., 401 $(k)$ Plan Asset Allocation, Account Balances, and Loan Activity, EBRI Issue Brief No. 205, 5 (January 1999). During the period 1980 through 1994, 401(k) plans accounted for approximately 77 percent of the net increase in all private pension plans. See id.

123. See I.R.C. \$ 401(k)(2) (1994).

124. See John M. Vine, Cash or Deferred Arrangements: What's the Beef? What's at Stake?, 5 VA. TAX REv. 855, 863-65 (1986). Although the Service had previously ruled favorably to taxpayers with regard to constructive receipt, it considered changing its position. Congress intervened to preserve the status quo by enacting section $401(\mathrm{k})$ in 1978. See id.

125. See id.

126. See I.R.C. \& 401(m) (1994 \& Supp. IV 1998).

127. See Vine, supra note 124 , at 859-60.

128. See id. at 859 . However, such contributions were allowed for a short period between 1982-1987. See Don W. Llewellyn, Tax-Favored Deferred Compensation Plans-Tax Planning for Business Owners and Executives After the Tax Reform Act of 1986 and TAMRA, 42 TAX LAw. 435, 456 (1989). In a defined benefit plan, employee contributions must be maintained in a separate account for each employee, which is similar to maintaining a defined contribution plan. 
contribution limits than other qualified plans. The maximum CODA contribution was limited to $\$ 10,000$ in 1999,129 while other defined contribution plans allowed maximum contributions up to $\$ 30,000 .{ }^{130}$ This limitation may make CODAs less attractive than other qualified plans to the extent that employees demand high levels of tax-favored savings.

In the Small Business Job Protection Act of 1996, Congress added another option for voluntary employee participation, the Savings Incentive Match Plans for Employees (SIMPLE) retirement account. ${ }^{131}$ SIMPLE accounts were adopted as an attempt to increase access to retirement savings plans by employees of small businesses. ${ }^{132}$ Employers who are eligible to offer SIMPLE accounts must not have another qualified plan in place. ${ }^{133}$ Furthermore, employers can have no more than 100 employees who received at least $\$ 5,000$ of compensation from the employer during the preceding year. ${ }^{134}$

SIMPLE plans may be structured using IRAs or CODAs, but in either case they allow employees to make elective contributions, expressed as a percentage of their compensation, totaling up to $\$ 6,000$ per year. ${ }^{135}$ In addition, the employer is required to make a matching contribution of up to three percent of an employee's compensation, ${ }^{136}$ or a nonelective contribution of two percent of compensation for each eligible employee, regardless of actual participation. ${ }^{137}$

See I.R.C. $\$ 414(\mathrm{k})$ (1994); 2 BITTKER \& LOKKEN, supra note 42, I 61.4.3, at 61-60 n.59. Employee contributions are also subject to the constraints of section $401(\mathrm{~m})$ of the Code, which are designed to ensure that the plan is not structured to unduly benefit highly compensated employees. See id.

129. See I.R.S. Notice 98-53, 1998-46 I.R.B. 24 (stating inflation-adjusted figure under I.R.C. $\S 402(\mathrm{~g})(1))$.

130. See id. (stating inflation-adjusted figure under I.R.C. 415(c)(1)(A)).

131. See Small Business Job Protection Act of 1996, Pub. L. No. 104-188, $\S \S 1421-1422,110$ Stat. 1755, 1792-1801 (1996). See generally I.R.C. § 408(p) (1994 \& Supp. IV 1998).

132. See H.R. Conf. Rep. No. 104-737, at 235-37 (1996). As discussed below, proportionally fewer small businesses offer retirement savings plans for their employees as compared to their larger counterparts. See infra Part III.

133. See I.R.C. \& 408(p)(2)(D) (1994 \& Supp. IV 1998).

134. See I.R.C. $\$ 408(p)(2)(C)(i)$ (1994 \& Supp. IV 1998).

135. See I.R.C. $\$ 408(\mathrm{p})(2)$ (A) (1994 \& Supp. IV 1998).

136. See I.R.C. $\$ 408(\mathrm{p})(2)$ (A)(iii) (1994 \& Supp. IV 1998) (requiring matching contribution which "does not exceed the applicable percentage of compensation for the year"); $\S 408(\mathrm{p})(2)(\mathrm{C})(\mathrm{ii})$ (1994 \& Supp. IV 1998) (defining "applicable percentage" as 3 percent, with limited exceptions to elect a lower percentage under certain conditions).

137. See I.R.C. $\$ 408$ (p)(2)(B) (1994 \& Supp. IV 1998). It should be noted that this 2 percent nonelective contribution is limited to the maximum compensation limitation stated in I.R.C. \$ 407(a)(17). See I.R.C. \$ 408(p)(2)(B)(ii) (1994 \& Supp. IV 1998). This amount is currently $\$ 160,000$, as adjusted for inflation. See Notice $98-53,1998-46$ I.R.B. 24 . Thus, an employer's nonelective contribution may not exceed $\$ 3,200$ for any employee. 
Whether structured as SIMPLE 401(k) plans or as SIMPLE IRAs, these savings vehicles are treated similarly to other qualified plans, allowing tax deferral on contributions and income earned within the account until distributions are made. ${ }^{138}$ SIMPLE 401(k) plans are designed to avoid special nondiscrimination tests and so-called "topheavy" rules applicable to other 401 (k) plans. This feature may make SIMPLE 401(k) plans attractive to some employers, despite the lower contribution amounts. ${ }^{139}$

Voluntary participation in $401(\mathrm{k})$ and SIMPLE plans is desirable from the perspective of economic efficiency. ${ }^{140}$ Employees subject to high marginal tax rates who have high savings preferences may value tax-favored savings, while those with low marginal tax rates and a preference for consumption may heavily discount the value of future consumption during retirement. ${ }^{141}$ Thus, an employer's retirement plan contributions for employees who do not value them arguably causes a wasteful distortion.

Despite efficiency benefits, discretionary savings options fail to ensure retirement security for all workers. Tax incentives, on their own, may be insufficient to induce voluntary participation by those who have pressing needs for current consumption and/or lower marginal tax rates. An employer's matching contributions may encourage participation where tax incentives fall short, but only SIMPLE plans have a matching requirement. CODAs under section $401(\mathrm{k})$ do not require employers to make matching contributions, although employers may choose to make them in order to ensure compliance with anti-discrimination rules. ${ }^{142}$

138. See H.R. Conf. Rer. 104-737, supra note 132.

139. For a critical assessment of SIMPLE plans, see David M. Graf, 1996 Pension Simplification, 19 U. ARK. LiTrLe Rock L.J. 563, 563-65 (1997).

140. See Richard A. Ippolito, Pensions and Economics: Towards an Efficient Retirement Policy, in Search for a National Retirement Income Policy 3343 (Jack L. VanDerhei, ed. 1987).

141. See id. See also Bankman, supra note 12, at 805-12 (explaining similar efficiency concerns with respect to nondiscrimination provisions).

142. See Canan, supra note 9 , at $\$ 3.92[\mathrm{~A}][2]$, at 225-26.

The employer is not required to make matching contributions. However, most employers like the idea of encouraging employees to save, and a matching contribution normally encourages elective deferrals by employees. Matching a certain percentage of the employee's elective contribution is a way to encourage this practice. Also, a matching contribution is generally perceived as a way of encouraging non-highly compensated employees ... to increase their elective deferrals, which in turn helps the plan meet the actual deferral percentage [nondiscrimination] test. 


\section{Individual Retirement Accounts}

IRAs provide yet another example of a discretionary option for retirement savings. Employees without access to qualified plans originally had no opportunity for tax-favored retirement savings. In 1974, Congress addressed this gap in coverage by creating IRAs. ${ }^{143}$ IRAs allow individuals to make discretionary tax-deductible contributions of earned income, thus allowing savings to be funded with pretax dollars. ${ }^{144}$ Similar to qualified plans, IRA income accumulates without current taxation, thus allowing a larger pool of capital to accumulate for retirement. ${ }^{145}$ Income taxes are then imposed upon distribution. ${ }^{146}$

In their initial form, IRAs were available only to those who were not active participants in employer-provided retirement plans. ${ }^{147}$ In an attempt to increase savings rates, Congress eliminated this active participant limitation in the Economic Recovery Tax Act of 1981 (ERTA). ${ }^{148}$ However, unrestricted access to deductible IRAs proved short-lived. In the Tax Reform Act of 1986, Congress reverted to a

143. Employee Retirement Income Security Act of 1974, Pub. L. No. $93-406, \S 2002$ (a), 88 Stat. 829,959 (1974) (codified at I.R.C. $\$ 408$ ).

144. See I.R.C. \$219(a) (1994) (allowing a deduction for "qualified retirement contributions").

145. See I.R.C. $\$ 408($ e)(1) (1994). See also I.R.C. $\$ 408$ A(a) (1994 \& Supp. IV 1998) (prescribing treatment for Roth IRA in same manner as individual retirement plan).

146. See I.R.C. $\S 408$ (d) (1994 \& Supp. IV 1998).

147. Joint Committee on Taxation, General Explanation of the Tax Reform Act OF 1986625 (1987) [hereinafter "1986 BLUE BoOK"].

148. See id. The legislative history to ERTA states in part:

The committee has found that the present rules providing tax-favored treatment for individual retirement savings have become too restrictive in view of recent rates of inflation and because they do not sufficiently promote individual savings by employees who participate in employer-sponsored plans.

The committee bill is designed to promote greater retirement security by increasing the amount which individuals can set aside for retirement in an IRA and by extending IRA eligibility to individuals who participate in employer-sponsored plans.

S. Rep. No. 97-144, at 113 (1982). Expanding access to deductible IRA contributions significantly impacted participation. A recent Senate Report from the Special Committee on Aging made the following observations about the impact of ERTA:

The extension of IRAs to pension-covered workers in 1981 by ERTA resulted in dramatically increased IRA contributions. In 1982, the first year under ERTA, IRS data showed 12 million IRA accounts, over four times the 1981 number. In 1983, the number of IRAs rose to 13.6 million, 15.2 million in 1984, and 16.2 million in 1985. In 1986, contributions to IRAs totaled $\$ 38.2$ billion. Congress anticipated IRA revenue losses under ERTA of $\$ 980$ million for 1982 , and $\$ 1.35$ billion in 1983. However, according to Treasury Department estimates, revenue losses from IRA deductions for those years were $\$ 4.8$ billion and $\$ 10$ billion, respectively. By 1986 , the estimated revenue loss had risen to $\$ 16.8$ billion. Clearly, the program had become much larger than Congress anticipated.

S. REP. No. 105-36(I), at 69 (1997). 
policy of limiting access to tax-deductible IRA contributions, allowing only lower-income taxpayers to supplement employer-provided plans with deductible IRA contributions. ${ }^{149}$

The legislative history to the Tax Reform Act of 1986 suggests that curtailed access to IRAs was based on several considerations, including: (1) higher-income taxpayers, which as a group had the highest utilization of elective IRA contributions, "would generally have saved without regard to the tax incentives;" (2) the lower tax rates enacted as part of the 1986 Act would "stimulate additional work effort and saving," thus "eliminat[ing] the need for IRA deductions for higherincome taxpayers who participate in other tax-favored retirement plans;" and (3) greater availability of other elective plans allowed many higher-income employees to participate in tax-favored savings, thus reducing the need for additional options. ${ }^{150}$

Despite limiting access to deductible contributions, Congress chose to permit nondeductible contributions to IRAs (even for those persons who were ineligible because of participation in an employer-provided plan). ${ }^{151}$ A nondeductible contribution still provides future tax benefits in the form of tax deferral on associated earnings realized prior to distribution. This benefit remains even though the contribution does not generate a current-year tax benefit. Thus, these provisions provide an incentive for supplemental retirement savings, particularly for those who have already maximized elective contributions to other tax-favored retirement savings options.

In the Taxpayer Relief Act of 1997,152 Congress again expanded taxpayers' options for supplemental retirement saving through IRAs. First, Congress allowed additional spousal IRA contributions. Under prior law, active participation in an employer-provided retirement plan ${ }^{153}$ was attributed from one spouse to another, which subjected both spouses to limited eligibility for IRA contributions. ${ }^{154}$ Beginning

149. Tax Reform Act of 1986, Pub. L. No. 99-514, § 1101(a)(1), 100 Stat. 2085, 2411 (1986) (codified at I.R.C. $\$ 219(\mathrm{~g})$ ). As of 1999 , deductible IRA contributions for an active participant in a qualified plan are phased out beginning at adjusted gross income of $\$ 51,000$ (married filing jointly) or \$31,000 (single). See I.R.C. \$ 219(g) (1994 \& Supp. IV 1998). Special rules apply for spouses who are not active participants, see I.R.C. $\$ 219(\mathrm{~g})(7)$ (1994 \& Supp. IV 1998), and for married filing separately and living apart, see I.R.C. $\$ 219(\mathrm{~g})(4)(1994)$.

150. See 1986 Blue Book, supra note 147, at 626 . It should be noted that the lower tax rates enacted in the Tax Reform Act of 1986 were also short-lived, as higher marginal rates returned in 1993. See Pub. L. No. 103-66, §13202(a) (1993).

151. See 1986 Blue Book, supra note 147, at 626.

152. Taxpayer Relief Act of 1997, Pub. L. No. 105-34, 111 Stat. 788 (1997).

153. See I.R.C. $\$ 219(\mathrm{~g})(5)$ (1994 \& Supp. IV 1998) (defining "active participant").

154. See I.R.C. $\$ 219(\mathrm{~g})$ (1994 \& Supp. IV 1998), prior to amendment by $\S 301(\mathrm{~b})$ of Pub. L. No. 105-34. For married couples filing joint returns, eligibility phased out between $\$ 40,000$ to 
in 1998, attribution was removed, thereby allowing a spouse who is not an active participant in an employer-provided plan to contribute to his or her own IRA account, provided that the couple's total income did not exceed $\$ 150,000 .{ }^{155}$ This change may improve the retirement security of spouses (including those who do not work outside the home), as it allows them to contribute up to $\$ 2,000$ to their own account. ${ }^{156}$

The second major change in the Taxpayer Relief Act of 1997 was the addition of another tax-favored IRA savings plan known as the "Roth IRA."157 Unlike a traditional IRA, deductions are not allowed for contributions to a Roth IRA. ${ }^{158}$ Tax benefits from a Roth IRA occur after the contribution as "qualified distribution[s]."159 Related earnings are exempt from income taxation. ${ }^{160}$ Thus, the Roth IRA allows taxpayers to realize tax benefits in later years as compared with a traditional IRA. ${ }^{161}$

The Roth IRA allows participants to choose whether to pay income taxes currently, with the potential to receive tax-free distributions, as opposed to deferring current tax obligations by using the traditional IRA. The Roth IRA also allows contributions from participants who are above seventy and one-half years of age; a segment of society that is barred from contributing to traditional IRAs. ${ }^{162}$ Consequently, those who are still earning later in life have a further opportunity to provide tax-favored saving for future retirement needs.

$\$ 50,000$ of adjusted gross income, with certain additional adjustments. Starting in 1998 , this phase-out begins at $\$ 50,000$, and it increases to $\$ 80,000$ for 2007 and beyond. See I.R.C. $\S 219$ (g)(3) (1994 \& Supp. IV 1998).

155. See I.R.C. $\$ 219(\mathrm{~g})(7)(1994$ \& Supp. IV 1998). Eligibility is phased out between $\$ 150,000$ and $\$ 160,000$. See id.

156. Although one might question the equity of allowing this benefit to higher-income taxpayers, it should be noted that a working spouse would otherwise be entitled to tax-deferred savings in an employer-provided plan of potentially more than $\$ 2,000$, regardless of the spouse's income.

157. See Pub. L. No. 105-34, $\$ 302$ (a), 111 Stat. 788, 825 (1997) (adding new Code $\$ 408$ A). See generally Michael S. McKinney, Note, The Roth IRA - Will It Increase Savings?, 66 TENN. L. REv. 847 (1999).

158. See I.R.C. \& 408A(c)(1) (1994 \& Supp. IV 1998).

159. See I.R.C. $\$ 408$ A(d)(2) (1994 \& Supp. IV 1998). Qualification requires a five-year holding period in addition to one of the following additional criteria: (1) distribution occurs after the holder attains age $59^{1} / 2$; (2) distribution to a beneficiary (or the holder's estate) on or after death; (3) distribution on account of disability; or (4) special purpose distribution for first-time homebuyers. See I.R.C. $\$ 408 A(d)(5)$ (1994 \& Supp. IV 1998).

160. See I.R.C. $\S 408$ A(d)(1) (1994 \& Supp. IV 1998).

161. As discussed below, both types of IRA produce similar benefits if tax rates are stable. See infra Part II.C.

162. Compare I.R.C. $\S 408$ A(c)(4) (1994 \& Supp. IV 1998) (permitting Roth contribution after age 701/2) with I.R.C. $\$ 219$ (d)(1) (1994) (disallowing deduction for contributions if individual "has attained age $70^{1} / 2$ before the close of such individual's taxable year for which the contribution was made"). 
IRA participation is generally discretionary, and access depends on individual initiative to set up an appropriate account. ${ }^{163}$ Moreover, the usefulness of IRAs are constrained by current contribution limits of $\$ 2,000$ per individual, as compared with up to $\$ 10,000$ for $401(\mathrm{k})$ plans, and $\$ 30,000$ for other qualified pensions. ${ }^{164}$ Although IRAs provide savings opportunities for those without access to employerprovided plans (including the self-employed), these limited contribution amounts may be inadequate to meet the retirement savings needs of many people, particularly if they began saving later in their working lives. ${ }^{165}$

\section{Keogh Plans and Other Options for the Self-Employed}

Prior to the Self-Employed Individuals Tax Retirement Act of $1962,{ }^{166}$ tax-favored retirement savings plans were available only for employees. ${ }^{167}$ This approach favored incorporated businesses because shareholders could be categorized as employees. However, partners and sole proprietors were not treated as employees for this purpose. ${ }^{168}$ Congress sought to rectify this apparent disadvantage to the

163. A possible exception to individual initiative involves special provisions allowing employers to set up IRA accounts for their employees, including the Savings Incentive Match Plans for Employees (SIMPLE) and Simplified Employee Pension. See CANAN, supra note 9, at $\$ 4.7$ (SIMPLE) and $\S 4.8$ (SEP).

164. See I.R.C. $\$ 219$ (b)(1) (1994). SIMPLE and SEP plans using IRAs created by employers allow higher contribution limits for employees. See CANAN, supra note 9, at $\$ \$ 4.7$ to 4.8 .

165. Legislation has been introduced in 1999 to raise the $\$ 2,000$ contribution limit. See, e.g., H.R. 2574, $\$ 1103$ (1999) (proposing to raise the limit to $\$ 5,000$ ); H.R. 1379, $§ 23$ (b) (1999) (proposing to raise the limit to $\$ 3,000$ ). Another proposal would allow older workers to "catch-up" with additional retirement contributions. See H.R. 2488, § 1221 (1999). "Catch-up" contributions may be particularly important for parents who stayed at home to raise children and were previously unable to contribute to an IRA because of spousal participation. Although the expanded spousal contributions allowed beginning in 1998 may provide relief for stay-at-home spouses on a prospective basis, catch-up contributions would assist those returning to the workforce who could not participate in prior years. See supra note 154.

166. See Self-Employed Individuals Retirement Act of 1962, Pub. L. No. 87-792, 76 Stat. 809 (1962).

167. See H.R. REP. No. 87-378 (1962), reprinted in 1962-3 C.B. 261, which states in part:

The primary reason for the bill is to give self-employed persons access to retirement plans on a reasonably similar basis to that accorded corporate stockholder employees. It thus corrects a discrimination in present law under which self-employed individuals and partners are prevented from participating in retirement plans established for the benefit of their employees although owner-managers of corporations may do so.

Id. at 262 .

168. See id. 
self-employed by allowing them to contribute to qualified plans known as "Keogh" or "H.R. 10" plans. ${ }^{169}$

This solution proved incomplete, as lower contribution limits applicable to Keogh plans left unincorporated business owners at a disadvantage to their corporate counterparts for many years. ${ }^{170}$ However, the Tax Equity and Fiscal Responsibility Act of 1982 (TEFRA) ${ }^{171}$ eliminated this disparity for tax years beginning after 1983 by raising the contribution amounts for Keogh accounts and lowering the contribution amounts for other qualified plans. ${ }^{172}$ Changes enacted as part of TEFRA achieved substantial parity in the requirements applicable to the self-employed and other qualified plans for employees. ${ }^{173}$

Theoretically, current law provides self-employed business owners with essentially the same retirement saving options as their corporateemployee counterparts. As part of a Keogh plan, self-employed business owners may choose to establish defined benefit contribution pension plans, defined contribution pension plans, or cash and deferred arrangements. ${ }^{174}$ In addition, most self-employed business owners will also be eligible to adopt SIMPLE plans, ${ }^{175}$ or SEPS. ${ }^{176}$ As shall be discussed, these plans provide a significant advantage in accumulating wealth that can be used to provide replacement income in retirement. ${ }^{177}$ However, limitations and conditions on tax-favored status may make them an impractical option for self-employed business owners.

\section{Wealth Accumulation Advantages From Tax-Favored Treatment}

Tax-favored treatment provides a significant advantage in accumulating wealth for retirement. Tax deferral on contributions and their

169. See Employee Benefits Law, supra note 15, at 72. Representative Keogh, who sponsored the bill, was a member of the Committee on Ways and Means. It was numbered H.R. 10 in the House of Representatives. See H.R. ReP. No. 87-378 (1962), reprinted in 1962-3 C.B. 261.

170. For example, prior to parity provisions enacted in 1982, contributions for self-employed persons were limited to the lesser of 15 percent of income from self-employment or $\$ 15,000$, whereas contributions for employees could be up to 25 percent of compensation up to a maximum of $\$ 45,475$. See Joseph S. Bluestein \& Jack B. Levy, Owner Dominated Plans - Top-Heavy and H.R. I0 Plans, 353-2d T.M. A-1. Bluestein and Levy have suggested that many businesses incorporated solely because of the more liberal retirement savings benefits available to corporate businesses. See id.

171. Tax Equity and Fiscal Responsibility Act of 1982, Pub. L. No. 97-248, 96 Stat. 324 (1982).

172. See Joint Committee on Taxation, General. Explanation of the Revenue Provisions of THE Tax Eouity and Fiscal Responsibility ACT of 1982 301-02, 309-10 (1982).

173. See Bluestein \& Levy, supra note 170 , at A-1 to A-2; CANAN, supra note 9, at $\$ 5.1$.

174. See Individual Retirement Plans Guide, supra note 113, at II 3001.

175. See I.R.C. $\$ 408(\mathrm{p})(6)(A)$, (B) (1994 \& Supp. IV 1998).

176. See I.R.C. $\$ 408(\mathrm{k})(7)(\mathrm{A})(1994)$.

177. See infra Part II.C. 
related earnings effectively results in a tax exemption for a portion of the account. This exemption effect can be illustrated through the following example. Assume that a taxpayer with $\$ 1,000$ in earnings pays the applicable federal income taxes and invests the remainder under three different alternatives: (1) "Traditional IRA,"178 (2) "Roth IRA," and (3) a taxable investment subject to generally applicable timing rules (i.e., one that is not tax-favored). The taxpayer's investment return is 10 percent, and his marginal tax rate is 28 percent. Assume further that the initial investment and accumulated earnings are distributed to the taxpayer after one year, and that no penalties apply. ${ }^{179}$ Results under each alternative are summarized below:

Investment (after $28 \%$ tax)
$10 \%$ Return on Investment
Distribution
Tax at Distribution $(28 \%$ )
Available for Consumption

TraDITIONAL

ROTH

Taxable

IRA

IRA

Account

$\$ 1,000$

100

1,100

$\$ 720$

$\$ 720.00$

308

72

792

$\$ 792$

$\frac{\mathrm{n} / \mathrm{a}}{\$ 792}$

72.00

792.00

20.16

In this example, the Traditional IRA begins with an investment of $\$ 1,000$, which is $\$ 280$ greater than the other options because it allows investment of pre-tax dollars. The Roth IRA and the taxable account both require investments of after-tax dollars, leaving only $\$ 720$ available for investment after payment of $\$ 280$ in taxes. Although all investments earn a 10 percent return, the Traditional IRA generates a greater total return (i.e., $\$ 100$ versus $\$ 72$ ) because of the additional $\$ 280$ investment that is attributable to tax savings from the year of contribution. ${ }^{180}$

The $\$ 1,100$ distribution to the Traditional IRA owner reflects the additional investment and earnings. Both IRA accounts generate $\$ 792$ in cash available for consumption after taking into account taxes on distribution, which apply only to the Traditional IRA. In this situation, the additional $\$ 280$ investment in the Traditional IRA grew to $\$ 308$, which is the total tax due after distribution. Thus, the Traditional IRA could be viewed as divided into two separate accounts; one containing current year tax savings invested for the government, and

178. The "Traditional IRA" was used for simplicity. This alternative could also include employer-provided qualified plans or Keogh plans with similar tax features.

179. This one-year distribution assumption is a matter of computational convenience. An additional 10 percent tax may apply to early distributions or withdrawals. See I.R.C. § 72(t) (1994 \& Supp. IV 1998).

180. If this example had involved a multi-year investment, the Taxable Account would generate a lower return each year to the extent it had realized gains due to annual tax liabilities on those gains. 
the other containing the balance invested for the taxpayer. ${ }^{181}$ In contrast, the Roth IRA satisfied its tax obligations prior to contribution, allowing the entire balance to be invested for the taxpayer with no further tax due at distribution.

The taxable account generates only $\$ 771.84$, which is $\$ 20.16$ less than the amount obtained in the tax-favored IRAs. This difference is attributable to the tax imposed on the $\$ 72$ return from this investment, which was not imposed on the same earnings of either the Roth or Traditional IRA. ${ }^{182}$ Thus, the IRAs allow a tax exemption for earnings on the taxpayer's share of the investment, whether achieved through deferral in the Traditional IRA or specific exemption of earnings on after-tax contributions in the Roth IRA. ${ }^{183}$

The potential for tax-exempt earnings is attractive, yet, even greater benefits are available if reduced tax rates apply to future distributions. Suppose that the taxpayer in the previous illustration was subject to a marginal tax rate of only 15 percent in the year of distribution, instead of the 28 percent rate in the prior year. The results of a Traditional IRA, Roth IRA, and Taxable Account in each of these circumstances are shown below:

Investment (after $28 \%$ tax)

$10 \%$ Return on Investment

Distribution

Tax at Distribution (15\%)

Available for Consumption

\begin{tabular}{|c|c|}
\hline $\begin{array}{l}\text { TRADITIONAL } \\
\text { IRA }\end{array}$ & $\begin{array}{l}\text { RoTH } \\
\text { IRA }\end{array}$ \\
\hline$\$ 1,000$ & $\$ 720$ \\
\hline 100 & 72 \\
\hline 1,100 & 792 \\
\hline 165 & $\mathrm{n}$ \\
\hline$\$ 935$ & $\$ 79$ \\
\hline
\end{tabular}

ROTH

$\$ 720$

72

$\$ 792$
Taxable

ACCOUNT

$\$ 720$

72

792

10.80

\$ 779.20

181. See Marvin A. Chirelstein, Federal Income Taxation 93-94 (Rev. 8th ed. 1999).

182. $\$ 72 \times .28=\$ 20.16$. Recall, the tax due on the Traditional IRA was $\$ 308-\$ 280$ from prior-year tax savings plus the related earnings of $\$ 28$. No tax was apparently imposed on the $\$ 72$ earned on the balance of $\$ 720$ invested in this account.

183. Those favoring consumption taxation observe that the treatment of qualified retirement plans removes a "distortion" in income taxation by eliminating a tax on returns from savings. See Ippolito, supra note 140, at 37.

By eliminating the double tax on savings, pensions remove the distortion in the tax code favoring spending now and saving less for retirement. By "neutralizing" the decision to save for retirement - that is, by eliminating the double-tax distortion - pension tax policy offsets biases in the income tax system that induce workers to take shorter retirements and to have lower standards of living during retirement.

Id. at 37; Halpcrin, supra note 14, at 160 ("Since there is no consensus in favor of a consumption tax, it is, perhaps, understandable that supporters of such a change would seek indirect means of accomplishing their goal. Expanding the special treatment for pension and profit-sharing plans into what looks more like a general incentive for saving is one such route."); Weiss, supra note 7, at $1289 \&$ n.54 (noting that many economists who favor consumption taxation "defend the pension deduction because they regard it as the removal of a bad tax rather than as a subsidy, which they would oppose."). 
The Traditional IRA would provide $\$ 935$ available for consumption, as compared with only $\$ 792$ if tax rates had remained stable. ${ }^{184}$ In effect, the owner of the Traditional IRA is able to keep a portion of prior-year tax savings and the related earnings, which would otherwise be paid out in tax. In such circumstances, the Traditional IRA, or any other tax-favored investment with similar characteristics, would outperform the Roth IRA. However, both tax-favored options outperform the taxable account.

If tax rates increase, rather than decrease, the characteristics of the Traditional IRA can work against the taxpayer during the short time frame noted above. To illustrate, suppose that the taxpayer in the above example faced a 40 percent tax rate in the year of distribution, rather than the 28 percent rate in the prior year. The results in this situation are shown below:

Investment (after $28 \%$ tax)
$10 \%$ Return on Investment
Distribution
$40 \%$ Tax at Distribution
Available for Consumption

\begin{tabular}{|c|c|c|}
\hline $\begin{array}{c}\text { TradiTIONAL } \\
\text { IRA }\end{array}$ & $\begin{array}{l}\text { RoTH } \\
\text { IRA }\end{array}$ & $\begin{array}{l}\text { TAXABLE } \\
\text { ACCOUNT }\end{array}$ \\
\hline$\$ 1,000$ & $\$ 720$ & $\$ 720$ \\
\hline 100 & 72 & 72 \\
\hline 1,100 & 792 & 792 \\
\hline 440 & $\mathrm{n} / \mathrm{a}$ & 28.80 \\
\hline$\$ 720$ & $\$ 792$ & 763.20 \\
\hline
\end{tabular}

In such circumstances, only the Roth IRA provides a better result than a taxable account. Higher tax rates on deferred income in the Traditional IRA eclipse the benefit from tax exemption on earnings, thus making the taxpayer at hand worse off despite participating in a "tax-favored" account.

Several factors make it unlikely that "tax-favored" accounts will underperform taxable accounts with similar investments. First, the above example used a one-year time frame, whereas most retirement saving occurs over several years. Multi-year effects of compounding tax-exempt returns can offset even dramatic increases in tax rates. To illustrate, assume a single investment of $\$ 1,000$ in a Traditional IRA, which is compounded over twenty years with tax-exempt earnings of 10 percent per year. At the end of twenty years, this investment will be worth $\$ 6,727.50 .185$ Alternatively, assume that $\$ 720$ ( $\$ 1,000$ less taxes of $\$ 280$ ) is invested in a taxable account which generates an after-tax return of 7.2 percent each year. ${ }^{186}$ At the end of twenty years, this investment will be worth $\$ 2,892.20,{ }^{187}$ which is less than half the

184. $\$ 1,100 \times .28=\$ 308$ tax at distribution, leaving $\$ 792$ available for consumption.

185. $\$ 1000 \times(1+.10)^{20}=\$ 6,727.50$.

186. The after-tax rate of 7.2 percent reflects 28 percent tax imposed on annual earnings of 10 percent, which is identical to the IRA investment.

187. $\$ 720 \times(1+.072)^{20}=\$ 2.892 .20$. 
amount in the tax-favored account. Thus, even in the unlikely event that tax rates double in the year the taxpayer takes a distribution from the IRA, the tax-favored account remains preferable to the taxable account. ${ }^{188}$

Second, post-retirement income levels are typically at or below income levels during working years. ${ }^{189}$ Absent legislative efforts to increase tax rates, movement to a higher tax bracket after retirement is unlikely, unless tax-favored account balances are distributed in a taxable lump sum. ${ }^{190}$ If tax-favored accounts are used to provide annual retirement income, average tax rates applicable to retirement income are likely to be lower than the marginal rates generating tax benefits in the year of contribution.

To illustrate, assume that in 1999 a married taxpayer has adjusted gross income of $\$ 56,000$, after taking into account an excludable (or deductible) contribution of $\$ 10,000$ to a tax-favored account. Using the standard deduction of $\$ 7,200,{ }^{191}$ and personal exemptions totaling $\$ 5,500$ for the couple, ${ }^{192}$ their taxable income would total $\$ 43,300 .{ }^{193}$ The total tax due on that amount would be $\$ 6,527.50,{ }^{194}$ for an average tax rate of 11.65 percent. ${ }^{195}$ Since income over $\$ 43,050$ is taxed at a marginal rate of 28 percent, ${ }^{196}$ the taxpayer would obtain a currentyear tax benefit totaling $\$ 2,800$ from $\$ 10,000$ of retirement savings.

Assume further that upon retirement this taxpayer fully replaces his pre-retirement earnings (other than the $\$ 10,000$ devoted to retirement

188. In this example, tax rates would have to increase to more than 57 percent before the taxfavored account becomes disadvantaged. The after-tax value of the IRA at 57 percent tax rate is computed as follows: $\$ 6,727.50-(\$ 6,727.50 \times .57)=\$ 6,727.50-\$ 3,834.68=\$ 2,892.83$.

189. See Jonathan Barry Forman, Universal Pensions, 2 Chapman L. Rev. 95 (1999) ("Financial Planners usually say that an individual needs a retirement income equal to about 60 percent to 80 percent of pre-retirement earnings."). However, a significant number of retirees are unsatisfied with the amount they do save. A 1998 survey by the Employee Benefits Research Institute indicates that 20 percent of retirees have a retirement experience that is worse than expected in terms of their overall standard of living. Employee Benefit Research Institute, Summary 1998 Retirement Confidence (visited June 9, 2000) <http:/www.ebri.org/rcs/1998_results.html>.

190. Special treatment for lump sum distributions was available prior to December 31, 1999 , and to certain other pension participants who received "grandfathered" eligibility for an averaging method. See generally Bob G. Kilpatrick \& Dennis R. Lassila, Income Tax Strategies for Lump Sum Distributions, 91 J. TAX'N 95 (1999).

191. Rev. Proc. $98-61,1998-52$ I.R.B. 18 , at $\$ 3.05$ (listing $\$ 7,200$ standard deduction for married couples filing joint returns).

192. Id. at $\$ 3.08$ (stating that the individual personal exemption amount is $\$ 2,750$ and that the total personal exemption for a couple is $\$ 5,500)(2 \times \$ 2,750=\$ 5,500)$.

193. $\$ 56,000-\$ 7,100-\$ 5,400=\$ 43,500$.

194. Rev. Proc. $98-61$, supra note 191 at $\$ 3.01$. This figure is derived as follows: $(\$ 43,050 \times$ $.15)+(\$ 250 \times .28)=\$ 6,457.50+\$ 70=\$ 6,527.50$.

195. $\$ 6,527.50 \div \$ 56,000=11.65$ percent.

196. See Rev. Proc. 98-61, supra note 191 , at $\$ 3.01$. 
savings) through distributions from a tax-favored retirement account. ${ }^{197}$ Given constant tax rates and deductions, this taxpayer would have an identical taxable income and tax liability as compared with the prior year. ${ }^{198}$ Distributions would therefore be taxed at an average rate of 11.65 percent which is considerably lower than the 28 percent rate at which tax benefits accrued during prior earning years. As a result, many retirees can expect to reap tax-exempt earnings on their own hypothetical share of the tax-favored account. ${ }^{199}$ Additionally, retirees could also expect to expand that share by lowering their average tax rates in the year of distribution, even if nominal tax rates remain the same.

\section{Conditions and Restrictions Affecting Participation and Access to Retirement Funds}

Given these significant advantages in wealth accumulation, tax-favored accounts should be the preferred vehicle for retirement saving. Nevertheless, tax incentives alone may be insufficient to induce voluntary participation in retirement savings plans. As indicated previously, voluntary participation is desirable from the perspective of economic efficiency. ${ }^{200}$ However, current retirement security policy operates on a more pessimistic and paternalistic assumption: "Whether because of the long time horizon, the press of more immediate needs, or the uncertainty of mortality, many people cannot or will not provide for their own retirement security." 201

Based on their approaches to retirement saving, Professor Deborah M. Weiss suggests several classifications for people including myopes, impulsives, impatients, and deliberates.

Some people, whom I will call myopes, simply do not think very much about the future. They spend money as they receive it. When they retire they are forced to lower their consumption level, and they regret not having saved more. Other people, whom I will call impulsives, worry about providing for their old age, and continually

197. If this taxpayer also drew social security benefits, a portion of those benefits may be excludable from taxable income. See I.R.C. $\$ 86$ (1994 \& Supp. III 1997).

198. See supra note 187 and accompanying text. The tax due might even be lower due to additional standard deductions allowed to taxpayers ages 65 and over. See I.R.C. \$ 63(f) (1994) (allowing additional exceptions for the aged). For 1999, this deduction amounted to $\$ 850$ for each married taxpayer aged 65 and over. See Rev. Proc. 98-61, 1998-52 I.R.B. 18, § 3.05(3).

199. See supra note $179-80$ and accompanying text.

200. See supra note 140 and accompanying text.

201. Halperin, supra note 14, at 161. See also Weiss, supra note 7, at 1275 ("Left to their own devices, many people will not save enough for their old age. This hard truth about human behavior has led American government to make a long and expensive commitment to retirement security programs."). 
resolve to save more, but find that money burns a hole in their pocket. Such people spend their paycheck the moment they receive it. On Monday they regret the impetuousness of Friday, and promise themselves not to repeat it, yet they find next Friday that temptation is again too great. Still another group, whom I will call impatients, always believe that present consumption needs are especially pressing. Although they see the need to save for future consumption, they believe that it will be easier to save from next year's wages than from this year's. But when next year comes, current consumption seems more pressing than it did in previous years, and the amount that they ultimately save for retirement is far less than what they anticipated while young .... Impatients have no cycle of Friday binges and Monday morning regret, but rather plan consciously to spend more this year than next. Finally, some people, whom I will call deliberates, plan when young to consume less as they grow old, and follow this consumption plan without any later regret. $^{202}$

As these classifications suggest, some decisions not to participate in retirement savings plans may be irrational or misinformed, reflecting impulsive behavior or unrealistic appraisals of current and future consumption needs. These nonparticipants later regret their decisions, much like the grasshopper. ${ }^{203}$ Other people choose not to save based on realistic perceptions of current and future consumption needs. For example, educating children or paying medical expenses may be viewed as more important than saving for future consumption during retirement, particularly if one believes that retirement savings can be increased in later years. ${ }^{204}$

Finding a principled basis to evaluate which of these categories applies in a given period proves elusive. ${ }^{205}$ Determining the appropriate level of replacement income after retirement is a normative choice. Thus, it is difficult to prescribe an effective policy tool that will help only those who will have regrets. Nevertheless, employer-provided plans apparently operate on the assumption that most people would prefer additional retirement income (over and above Social Security benefits) if they knew what was good for them. Conditions on tax-

202. Weiss, supra note 7 , at $1285-86$.

203. See discussion supra Part I.

204. It should be noted, however, that a significant increase in the savings rate may be required to match the effects of tax-deferred compounding for retirement saving done far in advance of retirement. For example, a 20 year-old who makes a one-time IRA investment of $\$ 1,000$ and allows it to compound for 45 years at a 10 percent rate of return would accumulate $\$ 72,890\left(\$ 1,000 \times(1+.10)^{45}\right)$ at age 65 . In contrast, a 45 year-old saver making annual contributions of $\$ 1,000$ with a 10 percent return would accumulate only $\$ 57,275$ by age 65 .

205. See Weiss, supra note 7 , at 1286 (noting that economic theory assimilates all four cases to deliberate preferences of consumption to saving). 
favored accounts are designed to encourage savings and to limit access to that sum by those who might otherwise prefer current consumption.

\section{Conditions Requiring Participation}

Some conditions imposed on employer-sponsored qualified retirement plans are designed to utilize other employees' attraction to tax benefits to expand participation. 206 Nondiscrimination provisions were first enacted in 1942 to address the concern that tax-favored retirement savings opportunities should not be limited to the highly compensated. ${ }^{207}$ Minimum participation rules were enacted in connection with the Tax Reform Act of 1986 to supplement the nondiscrimination rules, thus ensuring that rank and file workers were included in retirement plans. ${ }^{208}$

In the intervening years the parameters of these provisions have varied and their desirability has been debated. ${ }^{209}$ Such rules may effectively force some employees to participate in employer-provided plans, even though they might prefer to receive cash compensation that could be used for current consumption. ${ }^{210}$ As a result, the rules are likely to increase the total cost of employer-provided retirement benefits over a system of purely elective participation. ${ }^{211}$

Whatever the merits of anti-discrimination provisions in facilitating employee participation in retirement saving, their impact on self-employed persons is unclear. On one hand, a self-employed person can presumably control whether a plan is adopted and the extent of his or her participation in that plan. In that sense, he or she is not "forced" to save. However, to the extent that nondiscrimination provisions increase employer costs, they may deter participation by small business owners with a significant proportion of employees who would prefer cash compensation rather than retirement saving. In this sense, the

206. See generally I.R.C. $\$ 401$ (a)(4) (1994) (addressing nondiscrimination generally); I.R.C. $\$ 410$ (b) (1994) (addressing minimum coverage standards).

207. See Employee Benefits Law, supra note 15, at 71-72. Professor Bankman points out that discrimination concerns were originally raised in hearings in 1937 , but the nondiscrimination rules were not enacted at that time. See Bankman, supra note 12, at 800-02.

208. See Bankman, supra note 12, at 803-04 \& n.71.

209. See, e.g., id. at 803; Nancy J. Altman, Rethinking Retirement Income Policies: Nondiscrimination, Integration, and the Quest for Worker Security, 42 TAx L. REv. 433, 433-83 (1987); Halperin, supra note 14, at 173-75; Bruce Wolk, Discrimination Rules for Qualified Retirement Plans: Good Intentions Confront Economic Reality, 70 VA. L. REv. 419, 419-71 (1984); Graf, supra note 139, at 569-72 (discussing legislative changes to nondiscrimination rules).

210. See Bankman, supra note 12, at 806-12.

211. Id. at 814 ("Under most plausible assumptions, the interference in the compensation mix [of nondiscrimination provisions] reduces the value of the wage package to the employee and increases labor costs to the employer."). 
small business owner's form of saving may be affected by the savings preferences of his or her employees.

\section{Restrictions on Access to Retirement Savings}

Once participation is secured, other conditions limit access to savings prior to retirement. These conditions vary depending upon the type of plan. Qualified pension plans must limit distributions to the following circumstances: (1) death; (2) retirement; (3) separation from service; or (4) disability. ${ }^{212}$ Plans that permit distributions at other times jeopardize their tax-favored status. ${ }^{213}$

Other retirement plans are more flexible. However, they still impose conditions that limit access to retirement funds. CODAs established under section $401(\mathrm{k})$, that are not also pre-ERISA moneypurchase plans, ${ }^{214}$ may allow for distributions in the case of "hardship." 15 "Hardship" is defined narrowly, requiring an "immediate and heavy financial need," 216 as illustrated through following example.

Generally, for example, the need to pay the funeral expenses of a family member would constitute an immediate and heavy financial need. A distribution made to an employee for the purchase of a boat or television would generally not constitute a distribution made on account of an immediate and heavy financial need. ${ }^{217}$

Regulations also state particular circumstances that are deemed satisfactory in meeting the "immediate and heavy financial need" requirement, including needs arising from certain medical expenses, costs

212. Treas. Reg. $\S 1.401-1$ (b)(1)(i) (as amended in 1976). These conditions are rooted in the definition of a pension plan, which is a plan:

established and maintained by an employer primarily to provide systematically for the payment of definitely determinable benefits to his employees over a period of years, usually for life, after retirement. . . A pension plan may provide for the payment of a pension due to disability and may also provide for the payment of incidental death benefits through insurance or otherwise. However, a plan is not a pension plan if it provides for the payment of benefits not customarily included in a pension plan such as layoff benefits or benefits for sickness, accident, hospitalization, or medical expenses (except medical benefits described in section $401(\mathrm{~h})$ as defined in paragraph (a) of $\$ 1.401-14)$.

Id.

213. See Rev. Rul. 74-254, 1974-1 C.B. 91 (denying tax-favored status to pension plan allowing distribution upon condition not described above)

214. See I.R.C. $\$ 401(\mathrm{k})(6)$ (1994) (defining pre-ERISA money purchase plan).

215. See I.R.C. $\$ \S 401(k)(2)(B)$ (1994) (listing events that allow for distribution of trusts to participants and beneficiaries); Treas. Reg. $\$ 1.401(\mathrm{k})-1(\mathrm{~d})(1)(\mathrm{ii})$ (as amended in 1995) (allowing for distribution of a profit sharing or stock bonus plan in the case of employee hardship).

216. Treas. Reg. $\$ 1.401(k)-1$ (d)(1)(ii) (as amended in 1995).

217. Treas. Reg. $\$ 1.401(\mathrm{k})-1(\mathrm{~d})(2)$ (iii) (as amended in 1995). 
incurred to purchase a principal residence or in preventing eviction from that residence, and certain tuition and educational expenses. ${ }^{218}$

In addition to satisfying the financial need requirement, the distributable amount is limited to that which is "necessary to satisfy the financial need." 219 This generally requires a written representation from the employee that the need cannot reasonably be relieved through other personal resources, such as loans, or ceasing employee contributions under the plan. ${ }^{220}$ A hardship distribution should apparently be used as a last resort, as opposed to a routine method of accessing funds.

Premature distributions from other qualified retirement plans and individual retirement accounts are generally allowed. Such distributions, however, are subject to a 10 percent excise tax. ${ }^{221}$ In the Tax Reform Act of 1986, Congress expanded the scope of this excise tax in order to prevent the diversion of retirement savings to non-retirement uses.222 However, the significance of the excise tax depends, in part, on the amount of tax-free buildup in the account. If an account has significant accumulated earnings, the participant is likely to benefit from tax savings despite the excise tax. ${ }^{223}$ For this reason, some commentators have suggested that penalties should be restructured to

218. Treas. Reg. $\$ 1.401(\mathrm{k})-1(\mathrm{~d})(2)$ (iv) (as amended in 1995).

219. Treas. Reg. $\$ 1.401(\mathrm{k})-1(\mathrm{~d})(1)(2)(\mathrm{iii})(\mathrm{B})$ (as amended in 1995).

220. Treas. Reg. $\$ 1.401(\mathrm{k})-\mathrm{l}(\mathrm{d})(2)(\mathrm{iii})(\mathrm{B})$ (as amended in 1995). The employer's responsibility is limited to obtaining the employee's representation, unless the employer has actual knowledge that it is false. Id.

221. See I.R.C. $\$ 72(t)$ (1994 \& Supp. IV 1998) (imposing a 10 percent additional tax on early distribution from qualified retirement plans).

222. See 1986 Blue Book, supra note 147, at 713-14. Some special rules may also apply. For example, SIMPLE plan distributions within the two-year period after the employee begins participation are subject to a 25 percent tax, rather than a 10 percent tax, as an additional disincentive for withdrawal. I.R.C. $\$ 72(1)(6)$ (1994 \& Supp. IV 1998) (allowing special rules for SIMPLE retirement accounts). Roth IRAs are also subject to a five-year limitation on withdrawals, even if the distribution occurs after age 591/2. I.R.C. $\$ 408$ A(d) (1994 \& Supp. IV 1998) (stating distribution rates).

223 . For example, consider the twenty year IRA which accumulated $\$ 6,727.50$ as compared with only $\$ 2,892.20$ in a taxable account. See supra note 183 . Even if the tax rate at distribution was 40 percent and a 10 percent excise tax applied, the IRA participant would still have $\$ 3,363.75(\$ 6,727.50 \times .50)$, and would thus be better off than having not participated in a taxfavored account. See also CANAN, supra note 9, at \$4.5[4] ("Assuming a 10 percent interest rate, an individual in the 25 percent tax bracket would have to accumulate an IRA for almost seven years before reaching the break-even point."); S. REP. No. 105-36(I), supra note 148, at 70 ("Most analysts agree that the additional buildup of earnings in the IRA, which occurs because the earnings are not taxed, will surpass the value of the 10 percent penalty after only a few years, depending upon the interest earned. Some advertising for IRA savings emphasized the weakness of the penalty and promoted IRAs as short-term tax shelters."). 
take into account more appropriate disincentives for premature withdrawals from retirement plans. ${ }^{224}$

Congress recently reduced the impact of this penalty excise on premature withdrawals by adding exceptions for certain targeted activities. The Taxpayer Relief Act of $1997^{225}$ allows taxpayers to make distributions from "qualified retirement plans"226 for certain medical expenses, without incurring the applicable penalty tax. ${ }^{227}$ The Act also allows penalty-free distributions from "individual retirement plans" 228 to pay health insurance premiums during a period of unemployment, ${ }^{229}$ "qualified higher education expenses" of the taxpayer, the taxpayer's spouse, or any child or grandchild of the taxpayer or spouse, ${ }^{230}$ and "qualified first-time homebuyer" costs. ${ }^{231}$

Arguably, the exceptions for home buying and medical expenses have a complementary relationship to achieving retirement security. Purchasing a home could be considered another form of retirement savings because home ownership may reduce the amount of replacement income required to sustain a retiree's standard of living. ${ }^{232}$ Medical expenses also relate to retirement security to the extent that they are necessary to reach retirement age, or to enjoy healthy living during retirement. However, the relationship between education expenses and retirement is more tenuous. ${ }^{233}$

224. See Weiss, supra note 7 , at 1283 n.31.

225. Pub. L. No. 105-34, 111 Stat. 788 (1997) (codified, as amended, in various sections of 26 U.S.C.).

226. "Qualified retirement plans" are defined in I.R.C. \$ 4974(c) (1994) to include both employer-provided qualified plans described in section 401(a) as well as IRAs. See I.R.C. § 72(t)(1) (1994).

227. I.R.C. \& 72(t)(2)(B) (1994 \& Supp. IV 1998).

228. An "individual retirement plan" is defined as either "an individual retirement account described in section 408(a) [or] . . an individual retirement annuity described in section 408(b)." I.R.C. \& 7701(a)(37) (1994). Thus, employer-provided qualified plans are excluded.

229. I.R.C. $\$ 72(\mathrm{t})(2)(\mathrm{D})$ (1994 \& Supp. IV 1998).

230. I.R.C. $\S \S 72(t)(2)(E), 72(t)(7)$ (1994 \& Supp. IV 1998).

231. I.R.C. $\$ \S 72(\mathrm{t})(2)(\mathrm{F}), 72(\mathrm{t})(8)$ (1994 \& Supp. IV 1998).

232. Moreover, home ownership is also highly tax-favored, given the combination of deductible mortgage interest, I.R.C. $\$ 163$ (1994 \& Supp. IV 1998), an exemption for capital gains on the sale of a principal residence, I.R.C. $\$ 121$ (Supp. IV 1998), and an exemption from taxation on imputed income from personal use.

233. To the extent that education contributes to the economic security of children, it arguably expands the safety net associated with family commitments. However, allowing existing IRA balances to be used for education also raises equitable concerns, as those who chose to save for education outside of an IRA were not able to reap the benefit of tax-deferred savings. The Taxpayer Relief Act of 1997 also contained other tax benefits for education, including the Hope Scholarship Credit, the Lifetime Learning Credit, and Education IRAs. See I.R.S. Notice 97-60, 1997-2 C.B. 310. An IRA distribution could be used to cover "qualified tuition and related expenses" and those expenditures are apparently eligible for either Hope Scholarship or Life- 
Although access to funds prior to retirement might jeopardize future retirement security in a particular case, such flexibility may also remove a potential barrier to participation. Lower-income taxpayers with few resources available to draw upon during a crisis may be discouraged from contributing to a retirement saving plan to the extent that they believe their funds will be unavailable in a time of need, or can be accessed only at significant cost. ${ }^{234}$ Thus, these provisions may ultimately enhance participation and retirement security for some taxpayers.

Loan provisions in retirement plans are also designed to address concerns about the potential need to access retirement funds. ${ }^{235}$ However, loans from IRAs are prohibited transactions causing a loss of tax-exempt status. ${ }^{236}$ Pledging an IRA as security for a loan also causes a taxable distribution in the amount pledged. ${ }^{237}$ Thus, the current rules for IRAs have the anomalous effect of allowing distributions that permanently deplete retirement savings without any means

time Learning Credits. See id. at 317-18. Thus, the IRA deferral can be effectively made permanent through these benefits.

234. Cf. S. ReP. 97-494, at 319-20 (1982).

The committee is concerned that widespread use of loans from tax-qualified plans and tax-sheltered annuities diminishes retirement savings. Accordingly, the committee concluded that restrictions on loans and pledges should be applied to all plan participants. However, the committee is also concerned that an absolute prohibition against loans might discourage retirement savings by rank-and-file employees who may need access to such monies for emergencies. Thus, the committee believes it appropriate to permit smaller loans which will not substantially diminish an employee's retirement savings.

Id. (emphasis added). See also Halperin, supra note 14, at 180 ("Low and moderate earners may have to be assured that if they need funds for unforeseen emergencies, they will at the least be no worse off than if they had not entered the plan in the first place."); Graetz, supra note 6, at 893 ("[T]he risks of long-term savings limited to retirement seem to bear disproportionately on low- and moderate-income workers who may be most concerned about access to such assets in times of emergency.").

235. See Halperin, supra note 14, at 180. Empirical evidence supports the proposition that loans increase the participation rate. See VanDerhei, supra note 122, at 6 n.6 ("Plans that make loans available ... have a higher proportion of employees participating in the plan, and participants in such plans contribute an average of 35 percent more to their accounts than participants in plans with no loan availability.").

236. See I.R.C. $\S 408(e)(2)(A)$ (1994) (prescribing loss of exemption for prohibited transaction, which includes loan to participant). See also I.R.C. \& 72(p)(4)(A) (1994 \& Supp. IV 1998) (omitting individual retirement accounts from the term "qualified employer plan" covered by above rules exempting loan transactions from being treated as taxable distributions); I.R.C. $\$ 4975$ (f)(6)(B)(i)(II) (Supp. IV 1998) (treating participant or beneficiary of individual retirement plan as shareholder-employee precluded from obtaining loan from plan). Similar rules prohibit loans from accumulated deductible contributions in a qualified plan. See I.R.C. $\$ 72(0)$ (1994).

237. See I.R.C. $\$ 408(e)(4)$ (1994). In contrast, labor regulations allow up to 50 percent of the participant's nonforfeitable accrued benefit in an employer-provided plan to be pledged as security for a loan from the plan. See 29 C.F.R. 2550.408b-1(f) (1999). 
to restore those amounts, while restricting loans that may only temporarily deplete retirement savings until repayment occurs. This effect may be viewed as a disadvantage for those who choose IRAs as their primary savings vehicle instead of employer-provided plans with loan provisions.

Qualified retirement plans other than IRAs are generally permitted to make loans to participants or beneficiaries if the loan:

(A) is available to all such participants or beneficiaries on a reasonably equivalent basis,

(B) is not made available to highly compensated employees (within the meaning of section $414(\mathrm{q})$ ) in an amount greater than the amount made available to other employees,

(C) is made in accordance with specific provisions regarding such loans set forth in the plan,

(D) bears a reasonable rate of interest, and

(E) is adequately secured. 238

Additional limitations apply in order to prevent a loan, which otherwise satisfies these conditions, from being treated as a taxable distribution. Section $72(\mathrm{p})$ of the Code provides that an otherwise permissible loan ${ }^{239}$ will not be treated as a constructive distribution "to the extent that such loan ... does not exceed the lesser of-(i) $\$ 50,000 \ldots$ or (ii) the greater of (I) one-half of the present value of the nonforfeitable accrued benefit of the employee under the plan, or (II) $\$ 10,000 . " 240$ This provision imposes a cap of $\$ 50,000$ on outstanding loans for participants with nonforfeitable accrued benefits of more than $\$ 100,000$. However, the provision allows a person with nonforfeitable accrued benefits of only $\$ 15,000$ to borrow at least $\$ 10,000.241$ These loans must also comply with certain terms, including repayment within five years (unless the loan is used to acquire the participant's principal residence $)^{242}$ and "substantially level amortization" over the term of the loan. ${ }^{243}$

Additional rules governing prohibited transactions do not allow plan loans to certain "disqualified persons," 244 including an "owner-

238. I.R.C. § 4975(d) (1994 \& Supp. IV 1998); 29 U.S.C. $\$ 1108(b)(1)$ (Supp. IV 1998) (containing similar provisions under ERISA).

239. A loan may be treated as a taxable distribution under section $72(\mathrm{p})$ without jeopardizing the tax-qualified status of the plan. See CANAN, supra note 9, at $\S 3.15$ [B][1] n.18.

240. I.R.C. $\& 72(\mathrm{p})(2)(\mathrm{A})$ (1994).

241. See Canan, supra note 9 , at $\$ 3.15[\mathrm{~B}]$. Special rules apply to plans with outstanding loans which affect the amount of new loans that can be made. Id.

242. See I.R.C. $\$ 72(\mathrm{p})(2)(\mathrm{B})(1994)$.

243. I.R.C. $\$ 72(\mathrm{p})(2)(\mathrm{C})(1994)$.

244. I.R.C. $\$ 4975$ (a) (Supp. IV 1998). The Code imposes an excise tax of 15 percent on a disqualified person with respect to a "prohibited transaction." Id. A "prohibited transaction" includes "lending of money or extension of credit between a plan and a disqualified person." 
employee," his or her family members, and certain related entities. ${ }^{245}$ For this purpose, an "owner-employee" is defined as "an employee who - (A) owns the entire interest in an unincorporated trade or business, or (B) in the case of a partnership, is a partner who owns more than 10 percent of either the capital interest or the profits interest in such partnership." 246 In addition, an "owner-employee" includes a "shareholder-employee," 247 which means "an employee or officer of an S corporation who owns (or is considered as owning within the meaning of section 318(a)(1)), more than 5 percent of the outstanding stock of the corporation on any day during the taxable year of such corporation." 248

Congress has recognized that "rank and file" employees need access to retirement funds in emergencies. ${ }^{249}$ However, the applicable rules do not restrict access based on annual income levels. Instead, the rules restrict only the size of plan loans, reflecting the view that "smaller loans" permitted by section 72(p) "will not substantially diminish an employee's retirement savings." 250 Although self-employed small business owners may earn modest incomes similar to "rank and file" employees, and may have the same need to access retirement funds on a temporary basis, the prohibited transaction rules nevertheless prevent self-employed business owners from accessing retirement savings through loans. To the extent that a small business requires additional investment to deal with a financial crisis or expanding needs, the inability to access retirement funds through borrowing may erect an additional barrier to participation.

\section{Restrictions on Investments}

Given their advantage in wealth accumulation, people who are disposed toward retirement saving should ordinarily choose a tax-favored retirement vehicle to hold their investments. ${ }^{251}$ Tax-favored

I.R.C. $\$ 4975$ (c)(1)(B) (1994). If the prohibited transaction is not corrected, a tax of 100 percent of the amount involved is imposed on the disqualified person. I.R.C. \$ 4975(b) (1994). Although certain loans are exempted from this tax on prohibited transactions, see I.R.C. $\$ 4975$ (d) (Supp. IV 1998), others are specifically excluded from this exemption. See I.R.C. $\$ 4975(\mathrm{f})(6)$ (Supp. IV 1998).

245. I.R.C. $\$ 4975$ (f)(6) (Supp. IV 1998)

246. I.R.C. $\$ 401$ (c)(3) (1994). Here, an "employee" includes a self-employed person. I.R.C. $\$ 401(\mathrm{c})(1)$ (1994). Family members include only brothers and sisters, a spouse, ancestors, and lineal descendants. See I.R.C. $\$ 267(\mathrm{c})(4)$ (1994).

247. I.R.C. $\$ 4975(f)(6)(B)$ (Supp. IV 1998)

248. I.R.C. $\$ 4975(f)(6)(C)$ (Supp. IV 1998).

249. See supra note 234 .

250. See supra note 234.

251. See supra Part II.C. 
vehicles are subject to certain restrictions, including fiduciary obligations and prohibited transaction rules, which can affect the available investment choices. These restrictions generally pose no problem for investors choosing publicly traded securities, mutual funds, certificates of deposit, or similar investments. However, they raise virtually insurmountable barriers for the self-employed business owner who would prefer to invest in his or her own business.

ERISA imposes fiduciary duties on trustees of "employee benefit plans," 252 which include four general obligations: (1) loyalty to participants and their beneficiaries, ${ }^{253}$ (2) prudence in the conduct of plan business and investment activities, ${ }^{254}$ (3) diversification of plan investments, unless "it is clearly prudent not to do so,"255 and (4) following plan documents when not inconsistent with ERISA requirements. ${ }^{256}$ Fiduciaries responsible for investing plan assets may be held responsible for losses if they are found to violate their duties of prudence or diversification. ${ }^{257}$

Pension plans that provide for individual accounts and allow participants or beneficiaries to exercise control over the investment of their pension assets may limit the extent of those fiduciary responsibilities. ${ }^{258}$ However, participant-directed investment may not free a fiduciary from ensuring access to an appropriate range of investment alternatives and appropriate information about those alternatives. ${ }^{259}$ Further, the fiduciary is generally not excused from responsibility for losses if the fiduciary acquiesces in making certain investments. ${ }^{260}$ Those investments which would expose a fiduciary to liability, even if directed by the participant, include loans to the plan sponsor, ${ }^{261}$ acqui-

252. See 29 U.S.C. $\S 1101$ (a) (1994) (defining coverage of provisions imposing fiduciary responsibilities); \$ 1104(a) (1994) (imposing "prudent man standard of care").

253. See 29 U.S.C. $\S 1104$ (a)(1)(A) (1994) (requiring discharge of duties "solely in the interest of the participants and beneficiaries and ... for the exclusive purpose of . . . providing benefits to participants and ... defraying reasonable expenses of administering the plan.").

254. 29 U.S.C. $\$ 1104(\mathrm{a})(1)(B)$ (1994) (requiring that the plan be conducted "with the care, skill, prudence, and diligence under the circumstances then prevailing that a prudent man acting in a like capacity and familiar with such matters would use in the conduct of an enterprise of a like character and with like aims.").

255. 29 U.S.C. $\S 1104(a)(1)(C)(1994)$.

256. 29 U.S.C. $\$ 1104(a)(1)(D)(1994)$.

257. See generally 42 U.S.C. $\$ 1109$ (1994).

258. See 29 U.S.C. $\$ 1104$ (c) (Supp. IV 1998).

259. See 29 C.F.R. § $2550.404 c-1$ (b) (1999).

260. See 29 C.F.R. $\$ 2550.404$ c-1(d)(2)(i) (1999).

261. See 29 C.F.R. $\$ 2550.404 c-1(d)(2)(i i)(E)(2)$ (1999). 
sition or sale of employer real property, ${ }^{262}$ and acquisition or sale of employer securities (except for certain publicly traded securities). ${ }^{263}$

The fiduciary obligations under ERISA are applicable to employerprovided qualified plans. The obligations are not applicable to Keogh plans unless employees other than a self-employed business owner participate in the plan. ${ }^{264}$ Additionally, the obligations do not apply to IRAs where participation is voluntary and the employer does not make contributions. ${ }^{265}$ However, an exception from the scope of ERISA's fiduciary obligations does not mean that a self-employed participant in a Keogh plan or an IRA has free choice in investments. The prohibited transaction rules in section 4975 of the Code that prevent loans also preclude other types of investment in the participant's business. ${ }^{266}$ Violation of these rules can result in excise tax liability for the participant of 15 percent of the amount involved, up to 100 percent if the prohibited transaction is not corrected promptly. ${ }^{267} \mathrm{An}$ IRA investment that violates section 4975 causes the IRA to lose its tax exemption. ${ }^{268}$

Thus, IRAs, Keogh plans, and other qualified plans can accommodate a broad range of investments within the parameters of the prohibited transaction rules and the applicable fiduciary obligations imposed by ERISA. However, the plans cannot accommodate business capital formation needs of the entrepreneur. Even though a selfemployed business owner may prefer saving and investment to consumption, the inaccessibility of tax-favored retirement savings for business needs may inhibit participation.

\section{Empirical Data on Participation}

The above discussion identified conditions that inhibit a small business owner's participation in tax-favored retirement savings, including restrictions on business investment and access to retirement funds. Empirical studies of workers at small business firms provide indirect

262. See 29 C.F.R. § 2550.404c-1(d)(2)(ii)(E)(3) (1999).

263. See 29 C.F.R. $\$ 2550.404 \mathrm{c}-1$ (d)(2)(ii)(E)(4) (1999).

264. See 29 C.F.R. $\$ 2510.3-3$ (b) (1999). Spouses of owners are also excluded from the definition of an employee for purposes of this provision. Id.

265. See 29 C.F.R. $\$ 2510.3-2$ (d) (1999).

266. See I.R.C. $\$ 4975$ (c)(1) (1994). A prohibited transaction includes "sale or exchange, or leasing, of any property between a plan and a disqualified person" and "transfer to, or use by, or for the benefit of, a disqualified person of the income or assets of a plan" among the list of prohibited transactions. Although exemptions are available in some circumstances, such exemptions are not available to owner-employees. See I.R.C. $\$ \$ 4975$ (c) (1994 \& Supp. IV 1998), 4975 (f)(6) (Supp. IV 1998).

267. See I.R.C. $\$ \$ 4975$ (a) (Supp. IV 1998), 4975(b) (1994).

268. See I.R.C. \& 408(e)(2) (1994). 
evidence that the owners of such businesses are not participating, and that capital scarcity is probably an important reason behind their nonparticipation. ${ }^{269}$ Analysis of IRS Statistics of Income data for the 1997 tax year provides additional evidence that many self-employed persons do not participate in tax-favored retirement savings. ${ }^{270}$

\section{A. Employee Benefits Research Institute Surveys}

Workers at small firms are much less likely to be covered by an employer-sponsored retirement plan than workers in larger firms. ${ }^{271}$ Data from the Current Population Survey for 1997 indicates the following breakdown of access and participation for workers employed by firms of various sizes:

Table 1: Pension Plan Coverage of Workers based on EMPLOYER SizE ${ }^{272}$

\begin{tabular}{|c|c|c|c|c|c|c|}
\hline Firm Size & Workers & $\%$ of Total & $\begin{array}{l}\text { Workers } \\
\text { with } \\
\text { Employer- } \\
\text { Offered } \\
\text { Pension } \\
\text { Plan }\end{array}$ & $\begin{array}{c}\% \text { of } \\
\text { Workers }\end{array}$ & $\begin{array}{l}\text { Workers } \\
\text { Included in } \\
\text { Pension } \\
\text { Plan }\end{array}$ & $\begin{array}{c}\% \text { of } \\
\text { Workers }\end{array}$ \\
\hline Under 25 & 42394 & $29.32 \%$ & 8222 & $19.39 \%$ & 6030 & $14.22 \%$ \\
\hline $25-99$ & 18374 & 12.7 & & & & $35.83 \%$ \\
\hline $100-499$ & 19051 & $13.18 \%$ & 12110 & $63.57 \%$ & 9327 & $48.96 \%$ \\
\hline 500-999 & 8091 & $5.60 \%$ & 55975 & $73.85 \%$ & 4674 & $57.77 \%$ \\
\hline 1000 or more & 56671 & $39.20 \%$ & & $77.26 \%$ & 34097 & $60.17 \%$ \\
\hline Total Workers & 144581 & $100.00 \%$ & 78815 & $54.51 \%$ & 60711 & $41.99 \%$ \\
\hline
\end{tabular}

This data shows that more than 42 million workers are employed by firms with fewer than 25 workers, which represents nearly 30 percent of the total workforce. Only about 19 percent of these workers had employers who offered pension plans, and of the 19 percent, only about 14 percent participated in those plans. Firms with 25-99 workers fared slightly better. Both of these groups show participation levels significantly below those of larger firms. ${ }^{273}$

269. See infra part III.A.

270. See infra part III.B.

271. See Paul Yakoboski \& Pamela Ostuw, Small Employers and the Challenge of Sponsoring a Retirement Plan: Results of the 1998 Small Employer Retirement Survey, EBRI Issue BRIEF No. 202, 3 (October 1998).

272. Current Population Survey (A Joint Project Between the Bureau of Labor Statistics and the Bureau of the Census) Pension plan coverage of workers, by Selected Characteristics . . . . 1997 (All Races, Both Sexes), at Table NC8 (visited June 8, 2000) <http://ferret.bls.census.gov/ macro/031998/noncash/8_001.htm> [hereinafter CPS Table NC8 (1997)].

273. Yakoboki and Ostuw derive similar disparities from 1993 data. See Yakoboski \& Ostuw, supra note 271. 
In an attempt to evaluate the basis for this disparity in coverage, the Employee Benefits Research Institute recently conducted surveys "designed to gauge the views and attitudes of America's small employers (with 5 to 100 full-time workers) regarding retirement plans and related issues." 274 Although these surveys exclude the smallest employers, and self-employed persons who have no employees, they may nevertheless provide insight into the motivations and concerns affecting retirement saving plans by small business owners. ${ }^{275}$

According to EBRI's 1999 survey, 19 percent of respondents who did not offer retirement plans indicated that their "most important" reason for not offering a retirement plan benefit was that "revenue is too uncertain to commit to a plan;" 50 percent agreed that this was a "major" reason they did not offer a retirement plan. ${ }^{276}$ Other reasons for not offering a plan included the following: "A large portion of workers are seasonal, part time, or high turnover" (19 percent "most important," 42 percent "major"); "Employees prefer wages and/or other benefits" (17 percent "most important," 53 percent "major"); "It costs too much to set up and administer" (12 percent "most important," 30 percent "major"); and "Required company contributions are too expensive" (10 percent "most important," 51 percent "major"). ${ }^{277}$ A similar survey in 1998 showed comparable results, confirming that employee preferences, uncertain revenue, high administrative costs, and the expense of required company contributions topped the list as reasons for opting out of any offer to set up a retirement plan. 278

Administrative costs and burdens have long been considered barriers to participation. Consequently, Congress has periodically sought to address these concerns for smaller employers. ${ }^{279}$ These responses indicate that even reduced administrative burdens may not be enough to induce participation. As some commentators have pointed out,

274. See EBRI, The 1999 Small Employer Retirement Survey (SERS) Summary of Findings, at 6 (visited June 8, 2000) <http://www.ebri.org./sers/1999/serssummary.pdf> [hereinafter 1999 SERS Summary]. The 100 employee maximum for a "small employer" follows the criteria for SIMPLE plans eligibility under I.R.C. § 408(p)(2)(C)(i)(I) (Supp. IV 1998). See Yakoboski \& Ostuw, supra note 271 (discussing survey results for 1998, the first year of this survey).

275. The survey was conducted through fifteen minute telephone interviews with 301 companies with a retirement plan and 301 companies without a retirement plan. See EBRI, the 1999 SERS Summary, supra note, 274 at 6 . The authors state that "each sample should yield statistical precision of plus or minus six percentage points (with 95 percent certainty) of what the result would be if all businesses with five to 100 full-time workers were surveyed with complete accuracy." Id.

276. Id. at 2 .

277. $I d$.

278. Yakoboski \& Ostuw, supra note 271 , at 7.

279. See id. at 3-4. SEPs and SIMPLE plans are examples of these efforts toward reducing administrative burdens. See id. 
"while administrative issues matter, they are not the only factors involved in low plan sponsorship among small employers: lack of employee demand for retirement plans and uncertain revenue streams are equally important." 280 These commentators dismiss the overall indication of a lack of employee demand as a function of the type of workers who are typically employed by small businesses without retirement plans. Typically, the employees are "young, have relatively low earnings, have lower levels of education, and turn over more quickly - characteristics not associated with high demand for retirement savings." 281 However, the commentators point out that among employers with retirement plans, only 53 percent of such employers have retirement savings education programs. ${ }^{282}$ Thus, educational efforts may improve retirement savings demands among some employee groups.

Nevertheless, the significant concern about "uncertain revenue streams" suggests that financial ability to contribute is a limiting factor regardless of employee demand. ${ }^{283}$ When asked what changes would lead the employer to seriously consider offering a retirement plan, nearly two-thirds chose "increased company profits." 284 This particular response exceeded the following responses for a business tax credit: sponsoring a plan (64 percent); reduced administrative requirements (50 percent); demand from employees (49 percent); allowing key executives to save more in the plan ( 49 percent); and lengthening vesting requirements for employees ( 40 percent). ${ }^{285}$

To some extent, the revenue concern may reflect a misunderstanding of retirement savings options. For example, only 64 percent of small employers without a plan knew that a plan could be set up for less than $\$ 2000$, only 60 percent knew that administrative costs could be shared with employees, and only 55 percent knew that an employer was not legally obligated to match all employee $401(\mathrm{k})$ contributions. 286 A significant percentage of employers were either misinformed or uninformed about the nature of employer obligations, resulting in a possible overstatement of the perceptions of cost. ${ }^{287}$ However, to the extent that matching contributions may be necessary

\footnotetext{
280. See id. at 5 .

281. Id. at 6 .

282. See id. at 12.

283. See Yakoboski \& Ostuw, supra note 271, at 12.

284. See id. at 8.

285. See id. at 8-9.

286. See id. at 8 .

287. See id.
} 
either as a statutory requirement ${ }^{288}$ or as a means to ensure adequate employee participation, ${ }^{289}$ this cost sensitivity is not unfounded.

Although a small business employer could potentially limit out-ofpocket costs for employees by adopting a plan that relies on discretionary employee contributions, the stated concern about limited profits and uncertain revenues may also affect the owner's willingness to make contributions for his or her own account. If funds are needed to ensure that the business is able to meet its payroll, pay its debts, or expand, the owner may be unwilling or unable to participate. ${ }^{290}$ An employer's own inability to use a tax-favored account is likely to influence a decision not to make such a plan available to employees.

Although these surveys do not directly address the preferences and concerns of the self-employed small business owner with respect to his or her own retirement savings, the fact that workers are not covered suggests that their employers are also not covered. As stated earlier, access to Keogh plans, SEPs, SIMPLEs, or other qualified retirement plans are subject to conditions that are designed to include "rank and file" employees. ${ }^{291}$ Small business owners (or their employees) could independently contribute to IRAs. Generally, owners could not take advantage of more generous contribution levels in other retirement savings alternatives unless employees were also eligible to participate.

\section{B. Statistics of Income Data}

Tax return data provides an alternative source of information about small business owners' participation in Keogh, SEP, and SIMPLE plans. Statistics of income data compiled by the Internal Revenue Service for the 1997 tax year provides a basis to assess participation in these plans by self-employed business owners. ${ }^{292}$ Although this data is subject to several constraints, it appears consistent with the conclu-

288. See, e.g., I.R.C. $\S 408(\mathrm{p})(2)(\mathrm{A})$ (iii) (Supp. IV 1998) (allowing employers to match contributions to SIMPLE retirement accounts); I.R.C. $\$ 408(\mathrm{p})(2)(B)$ (i) (Supp. IV 1998) (allowing employer alternative nonelective contribution for SIMPLE plans); I.R.C. $\$ \S 401(\mathrm{k})(11)$-(12) (Supp. IV 1998) (allowing employer match or alternative nonelective contributions as alternative methods to meet nondiscrimination requirements for $401(\mathrm{k})$ plans).

289. See supra note 142 and accompanying text.

290. See supra note 28.

291. See supra notes 208-10; 1 CANAN, supra note 9, at $\$ 5.7$ (minimum benefits or contributions under "top-heavy" limitations of I.R.C. $\$ 416$ for qualified plans); $i d$. at $\$ 4.8$ [A] (required contributions and participation in SEP); id. at $\$ 4.9[\mathrm{~B}][2]$ (required employer match or contribution for SIMPLE).

292. Statistics of Income data are available online. See Therese Cruciano, Individual Income Tax Returns, Preliminary Data, 1999 (visited June 15, 1999) <http:/www.irs.ustreas.gov/prod/ tax_stats/soi/ind_gss.html>, in file 97INPREL.EXE. 
sion that many small business owners, like their employee counterparts, are not participating in such plans.

Table 1 summarizes key data for 1997 from Form 1040 returns containing either Schedule C (Profit or Loss From Business (Sole Proprietorship)) or Schedule F (Profit or Loss from Farming). This data includes aggregate figures for the returns filed, income reported for all returns, and stratified data based on the reported size of adjusted gross income on that return.

Table 1 indicates that taxpayers filed 19,061,224 returns with Schedule C, Schedule F, or both, for the 1997 tax year, ${ }^{293}$ suggesting that there were at least 19,061,224 businesses or farming operations in the form of sole proprietorships. Of this total, 13,390,341 returns reported taxable income on either Schedule C, Schedule F, or both, making them potentially eligible to participate in Keogh plan for self-employed persons. Contributions to such plans would be reported on Line 29 of Form 1040.294

Only 1,169,016 returns, or 6.13 percent, included Keogh plan contributions, for an average of $\$ 8,400$ per return. However, the indicated participation rate varies considerably when returns are stratified based on adjusted gross income levels. Not surprisingly, those persons in higher income strata contribute more and participate in greater percentages than those in lower income strata.

Although these figures provide some insight into participation by small business owners, they do not precisely reflect participation. On one hand, the figures may understate actual participation in tax-favored retirement savings by this group to the extent that some taxpayers with self-employment income may also be employees who are covered by an employer-provided plan. ${ }^{295}$ For example, an employee who participates in an employer-provided plan may also own a small

293. The figures presented are derived by the IRS through sampling. See Cruciano, Individual Income Tax Returns, supra note 292.

294. See instructions to Schedules C and F (1997), which direct that owner contributions are to be reported on Form 1040, line 28 (1997). On 1998 forms, the direct owner contributions are reported on line 29 of Form 1040.

295. See Treas. Reg. $\$ 1.401-10$ (b)(3)(ii) (1963), which provides:

An individual may be treated as an employee within the meaning of section 401 (c)(1) of one employer even though such individual is also a common-law employee of another employer. For example, an attorney who is a common-law employee of a corporation and who, in the evenings maintains an office in which he practices law as a selfemployed individual is an employee within the meaning of section 401(c)(1) with respect to the law practice. This example would not be altered by the fact that the corporation maintained a qualified plan under which the attorney is benefited as a commonlaw employee.

Id. See also Pulver v. Commissioner, 44 T.C.M. (CCH) 644, 650 (1982) (allowing Keogh contribution for royalty income by inventor who was also covered by employer-provided pension). 


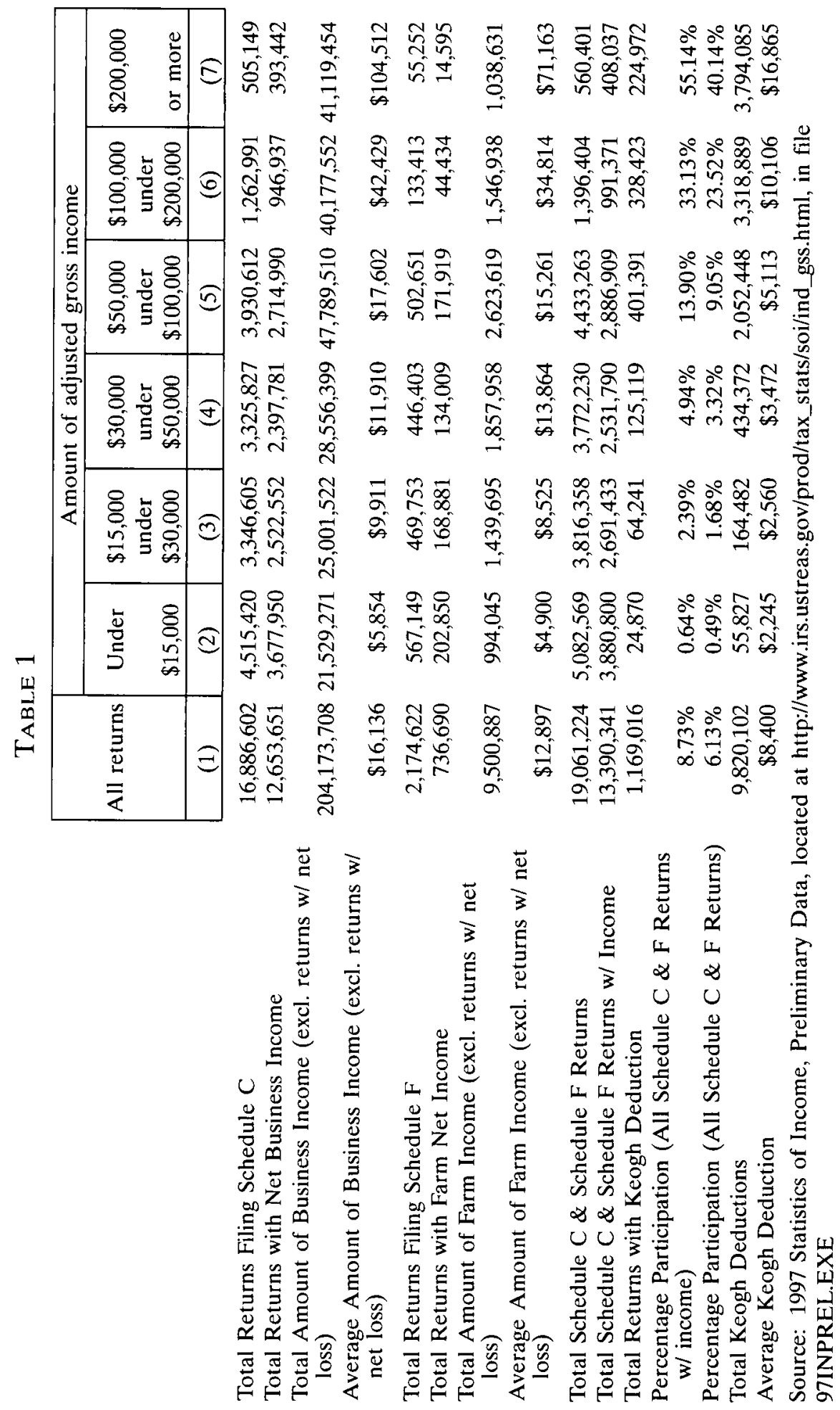


business or a farm that provides income from self-employment. Nonparticipation in a Keogh plan would be reflected in the above statistics, but it would not necessarily mean that the employee failed to receive the benefit of tax-favored saving through an employer-provided plan.

On the other hand, limiting the potential pool of participants to those filing Schedule C or Schedule F may also tend to overstate actual participation rates by self-employed persons. The "Keogh deduction" figures in the table above include contributions by partners ${ }^{296}$ eligible to contribute to a Keogh, SEP, or SIMPLE plans for a selfemployed person. ${ }^{297}$ Such contributions are reflected on line 29 of Form 1040 , in the same manner as contributions by a sole proprietor; 298 therefore, they would be included in the total contribution

296. The status of members of Limited Liability Companies (LLCs) are unclear under current law. On one hand, the default classification rule for LLCs provides for partnership taxation. See Treas. Reg. $\$ 301.7701-3$ (b) (as amended in 1998) (providing partnership classification as default rule). A partner's distributive share of partnership income may be considered income from selfemployment. I.R.C. $\$ 1402$ (a) (1994 \& Supp. IV 1998). However, the status of a limited partner's distributive share is uncertain. Proposed regulations defining a limited partner for selfemployment tax purposes have not been implemented. See Definition of Limited Partner for Self-Employment Tax Purposes, 62 Fed. Reg. 1702 (1997) (to be codified at 26 C.F.R. pt. 1) (proposed Jan. 13, 1997); Taxpayer Relief Act of 1997, Pub. L. No. 105-33, §935, 111 Stat. 788, 882 (1997). Self-employment income must also be classified as "earned income" in order to be eligible for contribution. See I.R.C. $\$ 401(\mathrm{c})(2)(\mathrm{A})(\mathrm{i})$ (1994) (defining "earned income" as including "earnings from self-employment" determined "only with respect to a trade or business in which personal services of the taxpayer are a material income-producing factor").

297. See I.R.C. $\S 401$ (d) (Supp. IV 1998), providing in part, that "contributions on behalf of any owner-employee may be made only with respect to the earned income of such owner-employee which is derived from the trade or business with respect to which such plan is established." I.R.C. $\$ 401$ (c)(3) (1994) defines an owner-employee to include "an employee who (A) owns the entire interest in an unincorporated trade or business, or (B) in the case of a partnership, is a partner who owns more than 10 percent of either the capital interest or the profits interest in such partnership." An "employee" for this purpose includes a "self-employed individual." I.R.C. $\S 401$ (c)(1)(A) (1994). The partnership is considered the employer of its partners, and thus only the partnership can establish a qualified plan for its partners, even though they are "self-employed." See I.R.C. \$ 401(c)(4) (1994) ("A partnership shall be treated as the employer of each partner who is an employee within the meaning of paragraph [401(c)](1)"); Treas. Reg. $\$ 1.401-10(\mathrm{e})(1)$ (1963) ("[A]n individual partner is not an employer who may establish a qualified plan with respect to his services to the partnership."). It should be noted that S-Corporation shareholders are not eligible to make Keogh contributions, even though they perform substantial services for the S-Corporation. See Durando v. United States, 70 F.3d 548, 1551 (9th Cir. 1995); No Go for Keogh Funded With S Corp. Income, 24 TAx'N Law. 305, 305-06 (1996). However, an S-Corporation may set up retirement plans that include shareholder-employees. Id . at 306 . Thus, benefits for S-Corporation shareholder-employees would not be reflected in these statistics. Id.

298. See instructions for Line 11 on Schedule K-1 (1997). The instructions state that this line includes: "Payments made on your behalf to an IRA, Keogh, simplified employee pension (SEP) or a SIMPLE plan. ... Enter payments made to a Keogh, SEP, or SIMPLE plan on Form 1040, line 29." 
amounts. Unless eligible partners also had sole proprietorships, their returns would not be counted in the total number of returns filed with Schedules C or F.

In 1997, 5,662,317 returns had income or loss from partnerships or S Corporations, with $3,599,488$ of these returns reporting income. ${ }^{299}$ Unfortunately, it is difficult to determine how many taxpayers filing these returns would have been eligible to make Keogh, SEP, or SIMPLE contributions. However, to the extent that any of these returns include eligible partners, they would tend to reduce the overall percentage of participation in Keogh, SEP, and SIMPLE saving plans.

\section{Tax Consequences of Business Investments AND Dispositions}

Although it would be desirable to have more empirical data specifically focused on retirement saving practices of small business owners, the data discussed herein suggests that a significant number do not participate in tax-favored savings. Capital formation needs, coupled with disadvantageous rules concerning access to retirement savings prior to retirement, help to explain this nonparticipation. One may also question whether business investments provide comparable tax benefits that diminish or eliminate any perceived disadvantage from nonparticipation in tax-favored retirement vehicles.

Accelerated deductions for investments in certain business assets and preferential tax rates for capital gains might be construed as providing benefits that are similar to tax-favored retirement accounts. However, those benefits do not adequately duplicate the wealth accumulation advantage of tax-favored retirement vehicles. Common tax attributes associated with the investment in, and disposition of, small business assets are discussed below.

\section{A. Investments In Business Assets}

Investments in assets with a useful life extending substantially beyond the close of the taxable year generally may not be deducted. Rather, such investments must be capitalized. ${ }^{300}$ The capitalized cost may be recovered on a tax-free basis, but the timing for that recovery differs among various types of assets. ${ }^{301}$ Timing has a potentially significant impact on the tax benefits available to the taxpayer. As a

299. See Cruciano, Individual Income Tax Returns, supra note 292.

300. See I.R.C. $\$ 263(\mathrm{a})$ (1994 \& Supp. IV 1998); Treas. Reg. $\$ 1.263(\mathrm{a})-2(\mathrm{a})$ (as amended in 1987).

301. See, e.g., Treas. Reg. $\$ 1.263($ a)-1(b) (as amended in 1993). 
general rule, it is better to accelerate, rather than defer, cost recovery. ${ }^{302}$

Property used in a trade or business that is subject to exhaustion, wear and tear, or obsolescence, is eligible for periodic cost recovery through depreciation. ${ }^{303}$ Prior to 1981 , tax depreciation was focused on estimating the total cost associated with the exhaustion of an asset over its expected useful life, and allocating that cost over that life. ${ }^{304}$ As the Supreme Court has explained:

The end and purpose of it all [depreciation] is to approximate and reflect the financial consequences to the taxpayer of the subtle effects of time and use on the value of his capital assets. For this purpose it is sound accounting practice annually to accrue as to each classification of depreciable property an amount which at the time it is retired will with its salvage value replace the original investment therein. Or as a layman might put it, the machine in its life time must pay for itself before it can be said to pay anything to its owner. ${ }^{305}$

Although the Court's description mentions an effect on "value," it is quite clear that historical cost, not actual market value, is the object of tax depreciation. ${ }^{306}$ Thus, this approach differs from an economic measure of depreciation, which focuses on the actual decline in value occurring each year. ${ }^{307}$

302. See generally Gertzman, supra note 45, at $\mathbb{1}$ 1.01[2] (discussing significance of timing issues).

303. See I.R.C. $\$ 167$ (a) (1994) (allowing "as a depreciation deduction a reasonable allowance for the exhaustion, wear and tear (including a reasonable allowance for obsolescence) . . . of property used in the trade or business"); Treas. Reg. $\$ 1.167(\mathrm{a})-2$ (1960) (tangible property); Treas. Reg. $\$ 1.167$ (a)-3 (1960) (intangible property with limited life); I.R.C. $\$ 197$ (1994) (amortization of goodwill and certain other intangibles).

304. See Treas. Reg. $\$ 1.167$ (b)-0 (as amended in 1964) ("Any reasonable and consistently applied method of computing depreciation may be used or continued in use under section 167 . Regardless of the method used in computing depreciation, deductions for depreciation shall not exceed such amounts as may be necessary to recover the unrecovered cost or other basis less salvage during the remaining useful life of the property.").

305. Detroit Edison Co. v. Commissioner, 319 U.S. 98, 101 (1943).

306. See, e.g., id. at 101; Fribourg Navigation Co. v. Commissioner, 383 U.S. 272, 277 (1966) ("[T]ax law has long recognized the accounting concept that depreciation is a process of estimated allocation which does not take account of fluctuations in valuation through market appreciation."). As Professor Kahn explains, this treatment is a function of realization principles.

Depreciation is an allocation of the cost an owner incurs in acquiring an exhaustible asset. The amount of cost that is allocable to the exhaustion of a portion of an asset's life should not be reduced or increased merely because external market conditions have changed the value of the remaining years of useful life: such unrealized appreciation or depreciation is not taken into account for tax purposes until realized.

Douglas A. Kahn, Accelerated Depreciation - Tax Expenditure or Proper Allowance for Measuring Net Income?, $78 \mathrm{MicH}$. L. Rev. 1, 31 (1979).

307. See 1 BitTKER \& LoKken, supra note 42, II 23.1.4, at 23-10; ChIRELSTEIn, supra note 181, at $154-55$. 
Deducting the expected salvage value from the total cost to be recovered through depreciation ensured that only the expected economic cost associated with the exhaustion of the asset was deductible. However, the total depreciation deducted for tax purposes would not always match the actual economic depreciation of an asset during its useful life. To the extent that a taxpayer deducted more than the economic depreciation, the taxpayer effectively received a tax benefit. ${ }^{308}$ The excess depreciation deduction may be recovered in a future year if the taxpayer disposed of the asset for more than its salvage value. However, the taxpayer retains the interim benefit of tax savings associated with the deduction. ${ }^{309}$

The proper method of allocating the depreciated cost among tax years has generated considerable academic debate. ${ }^{310}$ Professor Douglas A. Kahn outlined the core issues in his seminal article on this topic:

The principal controversy over depreciation turns upon the methods employed to allocate the cost or basis of the asset over the life of the asset. If the taxpayer recovers part of the cost of the asset earlier than is proper (i.e., if too much depreciation is allowed in the early years of the asset's use), the taxpayer obtains a benefit to the extent of the tax reduction caused by the excessive deduction. The unwarranted depreciation deduction might never be recaptured; even if it is recaptured, the taxpayer receives the use of the extra tax reduction dollars until the excessive deduction is recaptured. The taxpayer gains the value of deferring the tax until a later date, and the dollar benefit of a tax deferral can be quite substantial. ${ }^{311}$

In 1981, Congress ensured that businesses would reap tax benefits from depreciation by enacting the Accelerated Cost Recovery System, which abandoned the use of salvage value and generally allowed accelerated cost recovery over periods much shorter than the actual use-

308. Of course, a tax detriment could also result if the actual salvage value turned out to be less than the expected value. See Chirelstein, supra note 181, at 151.

309. It should be noted that the sale of the asset for more than its salvage value may be attributed to inflation. In that case, the depreciation deduction is arguably inadequate from an economic perspective. However, tax law does not take into account inflationary effects on depreciable assets. See $i d$. at 150-51.

310. See Kahn, Accelerated Depreciation - Tax Expenditure or Proper Allowance for Measuring Income? supra note 306, at 1-13; Water J. Blum, Accelerated Depreciation: A Proper Allowance for Measuring Net Income?!!, $78 \mathrm{MICH}$. L. Rev. 1172, 1184 (1980); Douglas A. Kahn, Accelerated Depreciation Revisited - A Reply to Professor Blum, $78 \mathrm{MiCH}$. L. Rev. 1185, 1185-98 (1980); Calvin H. Johnson, Kahn's Accelerated Depreciation Is Not Normative, 53 TAx Notes 858. 858 (Nov. 18, 1991); Douglas A. Kahn, Kahn Defends Stance of Accelerated Depreciation, 53 TAX NoTEs 1079, 1079-81 (Dec. 2, 1991).

311. See Kahn, Accelerated Depreciation - Tax Expenditure or Proper Allowance for Measuring Income?, supra note 306 , at 14. 
ful life. Professor Marvin A. Chirelstein describes the effect of this legislation as follows:

[T] he Code in 1981 pretty well abandoned the notion that depreciation should be spread out over an asset's true useful life and instead permits business taxpayer to depreciate their property over periods that are (and are expected to be) much shorter than the periods of actual service. In enacting the Acclerated Cost Recovery System (ACRS) . . . Congress' stated aim was to stimulate investment in plant and equipment, and with this overriding goal in view it simply discarded accuracy of measurement as an objective for the tax law to pursue. ${ }^{312}$

Regardless of one's views over whether accelerated depreciation methods result in tax benefits that are in excess of those allowed by normal income tax principles, ${ }^{313}$ allowing a depreciation deduction for the entire cost of a depreciable asset (including salvage value) over a recovery period that is generally shorter than the economic useful life, will clearly lower effective tax rates for business income. ${ }^{314}$

Section 179 of the Code allows eligible taxpayers to receive an additional tax benefit by electing to expense up to $\$ 20,000$ in expenditures that would otherwise be capitalized and recovered through depreciation. ${ }^{315}$ This election is generally available for tangible property that is used in a trade or business. ${ }^{316}$ The benefit is phased out to the extent that a taxpayer places in service more than $\$ 200,000$ of eligible property. ${ }^{317}$ An expense deduction under section 179 is allowed only to the extent of taxable income derived from the "active conduct by

312. Chirelstein, supra note 181 , at 151.

313. See supra note 309.

314. See 1 BitTKer \& LoKKEN, supra note 42, I 23.1.3, at 23-10 ("Even when the straight line method is used [under ACRS] . . depreciation is usually accelerated by shortened recovery periods and the rule allowing salvage to be ignored."). For a brief period, investment tax credits combined with depreciation deductions may have actually generated negative tax rates on certain business investments. See Joshua D. Rosenberg, Tax Avoidance and Income Measurement, 87 Mich. L. Rev. 365, 392 (1988) ("Between 1981 and 1984, the combination of accelerated cost recovery and the investment tax credit available to the purchaser of equipment could produce tax savings which, in present value terms, exceeded the tax that would be imposed on the income generated by the equipment. The result was, in effect, a negative rate of tax on income earned on certain investments.").

315. See I.R.C. $\$ 179$ (1994 \& Supp. IV 1998). The $\$ 20,000$ limitation is in effect for the year 2000. I.R.C. $\$ 179$ (b)(1) (1994 \& Supp. IV 1998). The limitation increases to $\$ 25,000$ for taxable years beginning in 2003 and beyond. $I d$.

316. See I.R.C. $\$ 179$ (d)(1) (1994) (limiting section 179 property to "tangible property (to which section 168 applies) which is section 1245 property (as defined in section 1245(a)(3)) and which is acquired by purchase for use in the active conduct of a trade or business. Such term shall not include any property described in section $50(\mathrm{~b})$ and shall not include air conditioning or heating units.").

317. See 1.R.C. $\$ 179(b)(2)$ (1994 \& Supp. IV 1998). 
the taxpayer of any trade or business." 318 In this way, the deduction cannot be used to offset passive investment income.

The combined effect of current depreciation rules and the election under section 179 to expense currently an otherwise capital expenditure, may allow a small business owner to achieve tax benefits from deferral. This effect is also experienced in a tax-favored retirement plan. For example, consider a contractor who invests $\$ 100,000$ in depreciable equipment used in her construction business. Assuming that the applicable limitations in section 179 are satisfied, she may currently deduct $\$ 20,000$. She would then be entitled to recover the remaining investment of $\$ 80,000$ through depreciation. Assuming a five year recovery period, ${ }^{319}$ the contractor would be entitled to deduct an additional $\$ 16,000$ in depreciation in the current year, ${ }^{320}$ and the balance of the investment would be recovered over the next five taxable years. ${ }^{321}$ Alternatively, if the taxpayer had not elected to expense a portion of this asset under section 179, the taxpayer would be entitled to deduct $\$ 20,000$ under section $168 .{ }^{322}$

This contractor is therefore eligible to take a total deduction of $\$ 36,000$ in connection with this investment; at least $\$ 16,000$ of this deduction is discretionary. ${ }^{323}$ The deduction is likely to exceed the amount that would otherwise be allowed under the pre-1981 measure

318. See I.R.C. $\$ 179($ b)(3) (1994 \& Supp. IV 1998). Income from the "active conduct of a trade or business" includes income as an employee, so that an employee who is also self-employed may obtain this benefit, even though the business in which the asset is used is not profitable in a particular year. See Treas. Reg. $\$ 1.179-2$ (c)(6)(iv) (1992) ("For purposes of this section, employees are considered to be engaged in the active conduct of the trade or business of their employment. Thus, wages, salaries, tips, and other compensation (not reduced by unreimbursed employee business expenses) derived by a taxpayer as an employee are included in the aggregate amount of taxable income of the taxpayer under paragraph (c)(1) of this section.").

319. See Rev. Proc. 87-56, 1987-2 C.B. 674, 678 (assigning 6-year class life and 5-year recovery period to asset class 15.0, which includes "assets used in construction by general building, special trade, heavy and marine construction contractors"), modified and clarified, Rev. Proc. 88-22, 1988-1 C.B. 785; I.R.C. $\$ 168($ e)(1) (1994 \& Supp. IV 1998) (property with class life of "more than 4 [years] but less than 10 [years]" treated as "5-year property"); I.R.C. $\$ 168$ (c) (Supp. IV 1998) (assigning 5-year recovery period to "5-year property").

320. See generally I.R.C. $\$ 168$ (1994 \& Supp. IV 1998) (applying 200 percent declining balance method, 5-year recovery period, half-year convention). This calculation is based on Rev. Proc. 87-57, Table 1, which illustrates the applicable depreciation percentage for year one is 20 percent. See Rev. Proc. 87-57, 1987-2 C.B. 687, 696.

321. See I.R.C. $§ 168$ (1994). Cost recovery occurs over six taxable years due to the half-year convention, which essentially treats any acquisition or disposition as occurring at the midpoint of the taxable year. See I.R.C. $\$ 168$ (d) (1994). No salvage value is taken into account. See I.R.C. $\$ 168(b)(4)(1994)$.

322. $\$ 100,000$ (cost basis) $\times .20$ (from Rev. Proc. $87-57$, Table 1$)=\$ 20,000$. See Rev. Proc. 87 57, $1987-2$ C.B. $687,696$.

323. Although the section 179 election allows a deduction up to $\$ 20,000$, that election reduces basis for depreciation purposes, thereby reducing depreciation by $\$ 4,000$. Thus, the net differ- 
of tax depreciation, which would have taken into account the economic useful life and expected salvage value of this equipment. 324 This excess arguably provides a current-year tax benefit that is similar to the benefit associated with an investment in a tax-favored account such as an IRA. ${ }^{325}$ The current-year reduction in tax burden associated with this deduction effectively provides a reduction in the effective tax rate on business income, which is similar to a tax-exemption on a portion of these earnings. ${ }^{326}$ However, unlike the tax-favored account, earnings from the business investment do not continue to enjoy tax-deferred treatment prior to disposition. The business asset may continue to generate taxable income after it has been depreciated; that income is fully taxable. Moreover, disposition of the business asset may also generate taxable income.

\section{B. Sales of Business Property}

Sales of depreciable business property can potentially recapture previously allowed depreciation deductions. For example, assume that the contractor in the above example ${ }^{327}$ sells her equipment during the following year for $\$ 100,000$, an amount that reflects no economic depreciation. The contractor will realize and recognize ordinary income from this sale in an amount that equals her prior year combined deductions under sections 179 and 168.328 Thus, economic income that avoided taxation in the first year is taxed at disposition, thereby ending the benefit of deferral.

The effect of the disposition is similar to a distribution from a taxfavored account such as an IRA, since prior deductions are effectively

ence is $\$ 16,000$. Deduction amounts under section 168 may also be affected by an election to use an alternative depreciation system under I.R.C. $\$ 168(\mathrm{~g})$ (1994 \& Supp. IV 1998).

324. It is also likely to exceed the amount of economic depreciation on the asset. However, as Professor Kahn points out, the limitations imposed by the realization requirement may make this an inappropriate benchmark. See supra note 306 .

325. See supra Part II.C.

326. See ChIRELStein, supra note 181 , at 159 .

327. See supra note 318 and accompanying text.

328. To illustrate, if the taxpayer had deducted $\$ 20,000$ under section 179 and depreciation of $\$ 16,000$ under section 168 , the adjusted basis at the beginning of the second year would be $\$ 64,000$. See I.R.C. $\$ 1016(\mathrm{a})(2)$ (1994). In the second year, the taxpayer would be required to deduct depreciation of $\$ 10,240$, as the half-year convention treats this asset as disposed of midway through the taxable year. See I.R.C. $\$ 168$ (d) (1994); Rev. Proc. 87-57 1987-2 C.B. 687, 696, Table 1. The adjusted basis of $\$ 53,760(\$ 64,000-\$ 10,240)$ is subtracted from the $\$ 100,000$ amount realized, producing a gain of $\$ 46,240$. The recapture provisions of I.R.C. $\$ 1245$ require that this gain is characterized as ordinary income. See I.R.C. $\$ 1245$ (1994 \& Supp. IV 1998). Thus, the net impact of this disposition is an ordinary gain of $\$ 46,240$ less $\$ 10,240$ in current-year depreciation, resulting in net income of $\$ 36,000$ - the same amount as the taxpayer deducted in the first year of ownership. 
recouped. ${ }^{329}$ Taxpayers face the potential for adverse tax consequences in these circumstances due to rate differentials between taxable years. For example, income from the sale of business assets may have pushed the taxpayer into a higher tax bracket, thus diminishing or perhaps even erasing the tax benefits from the prior year deduction.

Preferential tax rates associated with capital gains may reduce the impact of "bunching" income into a single tax year. ${ }^{330}$ Capital gain treatment, however, does not apply to gains associated with recaptured depreciation. ${ }^{331}$ A seller might also attempt to spread out taxable income through utilizing the installment method. ${ }^{332}$ It is important to note that the installment method does not provide an effective solution to this problem. Section 453(i) of the Code requires that any depreciation recapture associated with the asset must be taken into account in the year of disposition. ${ }^{333}$ Thus, even though a taxpayer may defer significant cash receipts until a future tax year, the tax associated with recaptured depreciation deductions is nevertheless accelerated.

This inability to dispose of business property and reinvest the proceeds without current tax consequences is a significant problem for the business owner who wants to retire from an active business. As long as the business owner continues to reinvest in business property, the tax impact of dispositions can be moderated through similar exchange provisions, which defer tax on otherwise realized gains. ${ }^{334}$ However, a taxpayer retiring from an active trade or business may need to reallocate his or her investment to other income-producing

329. See supra Part II.C.

330. See Zenz v. Quinlivan, 213 F.2d 914, 917 (6th Cir. 1954) ("The basic precept underlying the capital gains theory of taxation as distinguished from ordinary income tax is the concept that a person who has developed an enterprise in which earnings have been accumulated over a period of years should not be required to expend the ordinary income tax rate in the one year when he withdraws from his enterprise and realizes his gain.").

331. See I.R.C. \$1245(a)(1) (1994).

332. See I.R.C. $\$ 453$. The Ticket to Work and Work Incentives Improvement Act of 1999 eliminates the installment method for accrual basis taxpayers. See Pub. L. No. 106-170, §536, 113 Stat. 1860,1936 (1999). However, it remains available to cash basis taxpayers. See id. It should be noted that seller financing may also serve a nontax purpose of facilitating the sale. Seller financing may expand the pool of qualified purchasers (i.e., other capital-starved entrepreneurs). Small business advocates have expressed concerns about the impact of this amendment on business valuation. See, Karen Hube, Tax Rule Crimps Small-Business Deals, WalL St. J., Jan. 26, 2000, at C1.

333. See I.R.C. \$ 453(i) (1994). See John O. Everett, Structuring installment sales with recapture, $65 \mathrm{~J}$. TAx'N 66, 66 (August 1986). In addition, interest payments are required on deferred taxes for certain installment sales of assets over $\$ 150,000$. See I.R.C. $\$ 453 A$ (1994).

334. See I.R.C. $\$ 1031$ (1994 \& Supp. IV 1998). 
property, which cannot be done without tax consequences outside of a tax-favored account. ${ }^{335}$ Thus, the self-employed person faces a significant disadvantage in these circumstances as a result of having chosen to invest in a small business instead of in a tax-favored account.

\section{Dispositions at Death}

There is one potential advantage enjoyed by the business owner that is not available to the owner of a tax-favored account. The taxpayer may effectively prevent the government from recapturing prior tax benefits by dying while owning business property. ${ }^{336}$ Returning once again to the example of the contractor, assume that she passes away while owning the equipment and leaves it to her heir when it is worth $\$ 100,000$. In these circumstances, the heir can acquire a basis of $\$ 100,000$, the fair market value of the assets on the date of death. ${ }^{337}$ This disposition at death does not trigger a recapture of prior tax benefits by either the decedent or her heir. ${ }^{338}$ Thus, the decedent and her estate go untaxed, and the heir could sell the asset and recover $\$ 100,000$ tax-free. Additionally, the heir could utilize the asset to obtain depreciation deductions that will offset other taxable income from her own trade or business. ${ }^{339}$ On the other hand, if she had inherited a traditional IRA or similar tax-favored account, distributions from that account would still be treated as taxable income. ${ }^{340}$

335. It theoretically may be possible to achieve diversification through a tax-free reorganization or similar transaction, but such a transaction would generally require the cooperation of other investors who are willing to acquire an interest in the business property. For example, a small business owner in a sole proprietorship might choose to form a corporation with others who are able to provide diversified interests, allowing the retiring owner to achieve a passive investment interest in diversified holdings. However, other investors would presumably take into account the tax detriments associated with these assets in valuing the business owner's contribution. Moreover, this option is simply not practical for many small business owners, and it entails additional risks and transaction costs that are not incurred within tax-favored accounts.

336. See I.R.C. $\S 1014$ (1986 \& Supp. 1998).

337. See I.R.C. $\$ 1014(a)(1)$ (1986 \& Supp. 1998).

338. See I.R.C. $\$ 1014$ (c) (1986 \& Supp. 1998) (exempting "income in respect of a decedent under section 691" from section 1014). Section 691, which defines income in respect of a decedent, does not include depreciation recapture. I.R.C. $\$ 691$ (1986 \& Supp. 1998). However, income deferred under the installment method is considered income in respect of a decedent, which is taxable after death. See I.R.C. $\$$ 691(a)(4) (1986 \& Supp. 1998).

339. However, she could not elect to deduct this property under section 179 , as it is not acquired by "purchase" under section 179(d). See I.R.C. $\$ 179($ d)(2)(C)(ii) (1994) (excluding acquisitions where basis is determined by reference to $\S 1014(\mathrm{a})$ ).

340. See generally Gair Bennett Petrie, Estate Planning for Retirement Plans and IRAs, in PRICE, supra note 77, at 313-18 (Supp. 1998) (discussing income tax factors affecting the beneficiary of a spouse's retirement account). 
Section 1014 has endured in the Code despite considerable academic criticism. ${ }^{341}$ Among other things, section 1014 is criticized as aggravating the "lock-in effect," which inhibits redeployment of assets and investment in order to avoid the income tax effects. ${ }^{342}$ Untaxed gains under section 1014 also cause significant leakage in the tax system. ${ }^{343}$ Some commentators have proposed a rule of deemed realization at death. ${ }^{344}$ Such a rule causes potential liquidity problems for heirs who may require these assets to continue operating a family business. ${ }^{345}$ Alternatively, a carryover basis system, similar to that imposed on inter vivos gifts, would avoid this liquidity problem and ameliorate the "lock-in effect" associated with holding assets until death. ${ }^{346}$ Congress enacted a carryover basis system in 1976, but then repealed it retroactively in $1980 . .^{347}$ However, what Congress failed to accomplish in section 1014 has been accomplished for assets held in tax-favored retirement accounts. ${ }^{348}$

\section{Suggested Reforms}

Legislative efforts to provide similar opportunities for self-employed persons to participate in the wealth-building benefits of taxfavored retirement saving have fallen short of achieving parity with employees. This is principally due to the fact that current law fails to

341. See Lawrence Zelenak, Taxing Gains at Death, 46 VAND. L. Rev. 361, 363-67 (1993); Charles O. Galvin, Taxing Gains at Death, A Further Comment, 46 VAND. L. Rev. 1525, 1526-31 (1993); Joseph M. Dodge, Further Thoughts $n$ Realizing Gains and Losses at Death, 47 VAND. L. REV. 1827, 1829-38 (1994).

342. See Dodge, supra note 341 , at 1828 .

343. A 1994 estimate by the Congressional Budget Office indicated that the Treasury foregoes $\$ 9$ billion in tax receipts each year from untaxed gains at death, while other commentators suggest that it may be upwards of $\$ 30$ billion. See id. at 1828 n.4. The current estimate for fiscal 2001 is $\$ 28.24$ billion. See Treasury Dep't General Explanation of Clinton Administration's Fiscal Year 2001 Revenue Proposals, supra note 16, at Table 5-3, (showing "Major Tax Expenditures in the Income Tax, Ranked by Total 2001 Revenue Loss").

344. See Dodge, supra note 341 , at 1838-44.

345. See Zelenak, supra note 341 , at 367 (noting that carryover basis "imposes tax at a time when the taxpayer is likely to have cash available to pay the tax."); id. at 436 ("An important argument against taxation of capital gains at death is that the imposition of the tax on illiquid estates consisting largely of farms or small businesses could lead to forced sales to raise cash to pay the tax, thereby hastening the demise of the family farm and the small business person."). Liquidity concerns are also reflected in recent efforts to ameliorate the effects of the estate tax on family businesses. See H. REp. No. 105-148, at 355-56 (1997) (expanding access to installment payments "in order to better address the liquidity problems of estates holding farms and closely held businesses, to prevent the liquidation of such businesses in order to pay estate taxes.").

346. Cf. I.R.C. $\$ 1015$ (1994) (discussing generally the basis of property acquired by gifts and transfers in trust).

347. See Dodge, supra note 341 , at 1829 n.6.

348. See Fred B. Brown, "Complete" Accrual Taxation, 33 SAN DiEgo L. Rev. 1559, 1569-70 $(1996)$ 
take into account the capital formation needs of the entrepreneur. A significant number of self-employed business owners lack the practical ability to reap the wealth-building benefits of tax deferral, despite committing resources to investments that may also provide replacement income after retirement. Unlike nonsavers who choose a grasshopper's lifestyle of consumption, these entrepreneurs are models of ant-like behavior, though their savings efforts are treated disparately from their employee counterparts. Several reforms could ameliorate these differences and provide additional social benefits.

\section{A. Expanded Loan Availability and Penalty Exemptions}

Although restrictions on accessing retirement investments ensure that invested funds will be available at retirement, those restrictions may inhibit retirement saving, particularly by lower-income savers. ${ }^{349}$ Congress has responded by enacting exceptions from excise penalty provisions for funds withdrawn from IRAs in limited circumstances, including purchasing a first home, paying for medical expenses, and paying for higher education. ${ }^{350}$ Moreover, employer-provided plans may allow employees to borrow based on their retirement assets, thus providing emergency access to funds which is likely to enhance participation by lower-income taxpayers. ${ }^{351}$

Self-employed business owners lack similar options to access retirement account assets for business needs. IRAs cannot be used as collateral for a loan, and the limited exceptions to the excise penalty provisions do not cover business investments. ${ }^{352}$ Keogh plans are not eligible for the exceptions to the excise penalty provisions associated with IRAs, ${ }^{353}$ and prohibited transaction rules do not allow loans to a business owner for any purpose. ${ }^{354}$

Small business owners with profitable years may be willing to invest a portion of those profits in a tax-favored retirement account if they are assured that this capital will be available for emergency purposes, including future business investment. Eliminating penalty excise taxes on distributions used for business investments would be one approach to allowing access; expanded loan provisions would be another.

349. See supra note 236.

350. See supra notes 226-31.

351. See supra notes $239-43$

352. See supra notes 226-31 (distributions), 236-37 (loans). See also Kovach, supra note 23, at 170-71 (proposing loan provisions for IRAs to induce participation by rank and file employees).

353. See supra notes 226-31.

354. See supra notes $244-48$. 
Distributions from retirement accounts would reduce assets devoted specifically to retirement saving, though this would not necessarily have an adverse affect on retirement security. Social Security continues to provide a minimum safety net, therefore risk taking with discretionary retirement savings should not be problematic. After all, retirement accounts that permit self-directed investment do not proscribe high-risk investments. Paternalistic concerns should not overshadow the potential for enhancing personal economic growth in this context. The possibility of access is likely to encourage small business owner participation. Moreover, if such access is expanded to employer-provided accounts, it may also encourage business formation by employees who are willing to become entrepreneurs if they had access to capital. ${ }^{355}$

Changing the prohibited transaction rules to allow loans from Keogh plans and IRAs will also encourage participation. If loans from qualified plans are allowed for employees, it is difficult to justify the denial of a similar benefit to self-employed persons who also face financial needs, whether for business or otherwise. ${ }^{356}$ In fact, loans may present an even better option than penalty-free distributions, to the extent that they avoid current income tax effects associated with distributions and require continued commitment to long-term investment for retirement. Whereas business investments outside of tax-favored accounts can be converted to consumption, loan repayments will tend to ensure that capital is retained for retirement purposes.

\section{B. Expanded Contribution Options at Transition Events}

Contribution options should also be expanded to neutralize the tax impact of transitioning to retirement. Tax liabilities upon the disposition of business assets may significantly reduce assets available to provide replacement income for retirement years. ${ }^{357}$ Current rules defining income from self-employment, which is eligible for contribution to a tax-favored account, exclude gains from the sale of business assets. ${ }^{358}$ Thus, income from the sale of business assets cannot be

355. See supra note 24 (discussing capital scarcity as a limit on small business formation).

356. Recent legislative proposals have included expanded borrowing options, but to date these provisions have not been enacted. See H.R. 106-2488, \$ 1202 (1999) (proposing to exempt loans from prohibited transaction treatment); S. REP 106-1867, \& 103 (1999) (expanding availability of loans to owner-employees and shareholder employees with less than 25 percent ownership interests).

357. See supra note 335 .

358. See Treas. Reg. $\$ 1.1402$ (a)-6 (as amended in 1965). Characterization as a section 1231 asset does not affect eligibility. Regulations provide the following example to illustrate the concept of income from self-employment: 
used as the basis for a Keogh plan contribution during the year of the sale. ${ }^{359}$

Allowing gains from business property to be included in self-employment income and increasing the allowable contribution amount for the sale of business assets would ameliorate some of the disparate treatment associated with small business investment, as compared to a tax-favored account. For example, assume that a small business owner sells her business for $\$ 500,000$, and for simplicity assume that all the proceeds would otherwise be treated as taxable income. Allowing a contribution of $\$ 500,000$ to a tax-favored account would defer tax on this gain, permitting investment of $\$ 500,000$, rather than a significantly lower after-tax amount. ${ }^{360}$

In order to ensure that this provision is linked to enhanced retirement security, the allowable contribution amount could be tied to a maximum total balance of tax-favored accounts held by the taxpayer. For example, the total could be linked to an amount that would provide lifetime income equivalent to the maximum defined benefit allowed under an employer-provided plan. ${ }^{361}$ Limiting the total benefit

During the taxable year 1954 , A, who owns a grocery store, realized a net profit of $\$ 1,500$ from the sale of groceries and a gain of $\$ 350$ from the sale of a refrigerator case. During the same year, he sustained a loss of $\$ 2,000$ as a result of damage by fire to the store building. In computing taxable income, all of these items are taken into account. In determining net earnings from self-employment, however, only the $\$ 1,500$ of profit derived from the sale of groceries is included. The $\$ 350$ gain and the $\$ 2,000$ loss are excluded.

Treas. Reg. \$ 1.1402(a)-6(b) (as amended in 1965).

359. See 1.R.C. $\$$ 401(d) (Supp. IV 1998) (requiring plans for "owner-employees" to provide that "contributions on behalf of any owner-employee may be made only with respect to the earned income of such owner-employee which is derived from the trade or business with respect to which such plan is established."). I.R.C. $\$ 1402$ (c)(2) (1994) (defining "earned income" in relation to "net earnings from self-employment"). Such a contribution might be possible if the owner-employee had adequate earned income, but sales of business assets other than inventory would not constitute earned income. See Treas. Reg. 1.1402(a)-6(a)(i)-(ii) (as amended in 1965) (treating "stock in trade or other property of a kind which would properly be includible in inventory if on hand at the close of the taxable year ... [and] property held primarily for sale to customers in the ordinary course of a trade or business" as property that can give rise to income from self-employment).

360. Assuming that all of this gain is ordinary, (i.e., a sale of fully depreciated assets for no more than their respective original costs), the potential tax liability would be approximately $\$ 171,161$, leaving only $\$ 328,839$ to be invested for retirement income. See Rev. Proc. 98-61, 1998-52 I.R.B. 18 (Dec. 28, 1998), Table 1 - section 1(a) (1999 Tax Table for Married Filing Joint Returns).

361. As of 1999 , this figure is $\$ 130,000$. See supra note 93 . For example, a retiree with a life expectancy of ten years would be able to contribute $\$ 798,793.72$ assuming a 10 percent interest rate. (This figure represents the net present value of $\$ 130,000$ per year for ten years with a 10 percent return.). This approach would potentially allow different levels of tax benefits based on the taxpayer's age at disposition, which may have a distorting effect on retirement decisions. For example, someone retiring early might be able to defer tax on more income than a later retiree, 
in this manner ensures that this provision does not create a windfall for those who have already taken advantage of tax-deferred savings opportunities. Such a limit reflects the purpose of enhancing retirement security, rather than simply providing another means of tax avoidance.

Allowing small business owners to defer contributions to their own retirement accounts is unlikely to have an adverse effect on providing workplace retirement benefits for their employees. "Catch up" contributions are a second-best solution to tax-favored saving early in life, and this approach does not change that economic reality. Small business owners with available funds should still prefer saving in tax-favored form. Moreover, employee demand will continue to be an important factor in an employer's decision to offer a workplace retirement plan. ${ }^{362}$ Small business owners who are also employers will presumably meet these demands when it is cost effective to do so. ${ }^{363}$

Allowing deductible retirement contributions to offset income from the sale of business assets would also ameliorate the "lock-in effect" associated with the current rules of section $1014 . .^{364}$ This policy has the potential to provide a general economic benefit in ensuring that assets are deployed efficiently and productively, rather than held to avoid current tax consequences. Current-year revenue losses associated with deferring taxation on business gains may be partially offset by future taxation of distributions which would include income that will otherwise go untaxed under section 1014. Thus, enhanced retirement security and greater horizontal equity for small business owners may not be as costly to the public fisc as they might seem.

thus encouraging early retirement. An alternative approach based on a fixed level of maximum savings regardless of age may be preferable, as it would avoid potential distortions in retirement decisions under age-based formulas.

362. See supra note 275 and accompanying text (noting employee preferences considered "most important" factor by 17 percent of employers and "major" factor by 53 percent of employers considering retirement plans); see also supra note 285 and accompanying text (noting "increased employee demand" cited by 49 percent of employers as leading them to consider offering a retirement plan).

363. It may also be possible to use this alternative of tax-favored saving as a tool to encourage small business owners to establish workplace plans for their employees. However, such an approach must be sensitive to the costs imposed on small business owners, and the practical constraints of capital formation that otherwise appear to inhibit participation.

364. See supra part IV.C. 